\title{
Enhancing Astrocytic Lysosome Biogenesis Facilitates A $\beta$ Clearance and Attenuates Amyloid Plaque Pathogenesis
}

\author{
Qingli Xiao, ${ }^{1}$ Ping Yan, ${ }^{1}$ Xiucui Ma, ${ }^{2,3}$ Haiyan Liu, ${ }^{2}$ Ronaldo Perez, ${ }^{1}$ Alec Zhu, ${ }^{1}$ Ernesto Gonzales, ${ }^{1}$ Jack M. Burchett, ${ }^{1}$ \\ Dorothy R. Schuler, ${ }^{1}$ John R. Cirrito, ${ }^{1}$ Abhinav Diwan, ${ }^{2,3 *}$ and Jin-Moo Lee ${ }^{1 \star}$ \\ ${ }^{1}$ Department of Neurology and the Hope Center for Neurological Disorders and ${ }^{2}$ Division of Cardiology and Center for Cardiovascular Research, \\ Washington University School of Medicine, St. Louis, Missouri 63110, and 3 John Cochran VA Medical Center, St. Louis, Missouri 63108
}

\begin{abstract}
In sporadic Alzheimer's disease (AD), impaired $A \beta$ removal contributes to elevated extracellular $A \beta$ levels that drive amyloid plaque pathogenesis. Extracellular proteolysis, export across the blood-brain barrier, and cellular uptake facilitate physiologic $\mathrm{A} \beta$ clearance. Astrocytes can take up and degrade $\mathrm{A} \beta$, but it remains unclear whether this function is insufficient in AD or can be enhanced to accelerate $\mathrm{A} \beta$ removal. Additionally, age-related dysfunction of lysosomes, the major degradative organelles wherein $\mathrm{A} \beta$ localizes after uptake, has been implicated in amyloid plaque pathogenesis. We tested the hypothesis that enhancing lysosomal function in astrocytes with transcription factor $\mathrm{EB}$ (TFEB), a master regulator of lysosome biogenesis, would promote $\mathrm{A} \beta$ uptake and catabolism and attenuate plaque pathogenesis. Exogenous TFEB localized to the nucleus with transcriptional induction of lysosomal biogenesis and function in vitro. This resulted in significantly accelerated uptake of exogenously applied $\mathrm{A} \beta 42$, with increased localization to and degradation within lysosomes in C17.2 cells and primary astrocytes, indicating that TFEB is sufficient to coordinately enhance uptake, trafficking, and degradation of $A \beta$. Stereotactic injection of adeno-associated viral particles carrying TFEB driven by a glial fibrillary acidic protein promoter was used to achieve astrocyte-specific expression in the hippocampus of APP/PS1 transgenic mice. Exogenous TFEB localized to astrocyte nuclei and enhanced lysosome function, resulting in reduced $\mathrm{A} \beta$ levels and shortened half-life in the brain interstitial fluid and reduced amyloid plaque load in the hippocampus compared with control virus-injected mice. Therefore, activation of TFEB in astrocytes is an effective strategy to restore adequate $\mathrm{A} \beta$ removal and counter amyloid plaque pathogenesis in $\mathrm{AD}$.
\end{abstract}

Key words: Alzheimer's disease; amyloid; astrocytes; lysosomes; TFEB

\section{Introduction}

Astrocytes are the most abundant cell type in the brain and play a critical role in maintaining synaptic transmission and neuronal health in homeostasis (Eroglu and Barres, 2010). Astrocytes are activated in response to injury, with neurodegeneration (Barres, 2008), and in preclinical stages of Alzheimer's disease (AD; Schipper et al., 2006; Owen et al., 2009; Carter et al., 2012). Activated astrocytes surround amyloid plaques and neurofibrillary tangles, which are the neuropathological hallmarks of advanced AD (Funato et al., 1998; Nagele et al., 2003). Interestingly, in these studies, astrocytes demonstrate immunoreactivity for amyloid material, and experimental observations confirm that as-

Received Sept. 3, 2013; revised May 29, 2014; accepted June 6, 2014

Author contributions: Q.X., J.R.C., A.D., and J.-M.L. designed research; Q.X., P.Y., X.M., H.L., R.P., A.Z., E.G., J.M.B., D.R.S., J.R.C., and A.D. performed research; Q.X., P.Y., X.M., H.L., J.M.B., J.R.C., A.D., and J.-M.L. analyzed data; Q.X., J.R.C., A.D., and J.-M.L. wrote the paper.

This study was supported by grants from Alzheimer's Association (NIRG 12-242588 to A.D.), Brightfocus Foundation (A2012151 to J.R.C.), and from the National Institutes of Health (R21 NS082529 to J.-M.L. and R01 AG042513 to J.R.C.). The authors thank Dr. Katherine Ponder, Washington University, for assistance with Cathepsin assays.

${ }^{*}$ A.D. and J.-M.L. contributed equally to this work.

The authors declare no competing financial interests.

Correspondence should be addressed to either of the following: Dr. Jin-Moo Lee, Professor of Neurology; 660 South Euclid Avenue, CB 8111, St. Louis, M0 63110, E-mail: leejm@wustl.edu; or Dr. Abhinav Diwan, Assistant Professor of Medicine, 4940 Parkview Place, CSRB 827, St. Louis, M0 63110, E-mail: adiwan@dom.wustl.edu.

DOI:10.1523/JNEUROSCI.3788-13.2014

Copyright $\odot 2014$ the authors $\quad 0270-6474 / 14 / 349607-14 \$ 15.00 / 0$ trocytes can take up amyloid plaques and precursor $\mathrm{A} \beta$ peptides in animal models of AD (Wyss-Coray et al., 2003; Koistinaho et al., 2004). Despite these intriguing observations, the role of astrocytes in $\mathrm{AD}$ pathogenesis is under studied.

In $\mathrm{AD}$, an imbalance between the production and degradation of $\mathrm{A} \beta$ peptides drives increased extracellular levels in the interstitial fluid (ISF; Hardy and Selkoe, 2002) resulting in their concentration-dependent oligomerization and deposition as amyloid plaques (Lomakin et al., 1997). Recent studies implicate impaired $\mathrm{A} \beta$ removal as the dominant underlying mechanism in individuals with the more common sporadic forms of $\mathrm{AD}$ (Mawuenyega et al., 2010). Insights from animal models indicate that in addition to extracellular proteolysis and transport across the blood-brain barrier, $\mathrm{A} \beta$ can be taken up by astrocytes (WyssCoray et al., 2003; Koistinaho et al., 2004) and microglia (Mandrekar et al., 2009). We have observed that impairing astrocyte activation by ablation of intermediate filament proteins, glial fibrillary acidic protein (GFAP) and vimentin, results in increased plaque load (Kraft et al., 2013) pointing to a prominent role for activated astrocytes in countering amyloid pathogenesis. However, whether astrocyte function is inadequate (Wyss-Coray et al., 2003), and therefore needs to be stimulated to accelerate amyloid removal, remains unknown.

$\mathrm{A} \beta$ is taken up and trafficked to the lysosomes for degradation in astrocytes (Basak et al., 2012). Impairment of lysosome func- 
tion with aging (Kato et al., 1998; Cuervo and Dice, 2000; Wolfe et al., 2013), or with loss of presenilin, as observed in familial AD, (Lee et al., 2010; Coen et al., 2012) has been implicated in AD pathogenesis. It is suspected to be the underlying mechanism for accumulation of $\mathrm{A} \beta$ and phagocytosed amyloid material within astrocytes (Funato et al., 1998; Wyss-Coray et al., 2003), which may paradoxically promote amyloid plaque progression (Nagele et al., 2003). Recent studies demonstrate that activation of ubiquitously expressed transcription factor EB (TFEB) coordinately stimulates lysosome biogenesis and cellular trafficking pathways to promote breakdown of lipids and proteins to generate nutrients (Sardiello et al., 2009; Settembre et al., 2011, 2013b) and remove abnormal aggregates in lysosome storage disorders (Settembre et al., 2013a). In this study, we evaluated whether targeted expression of TFEB in astrocytes stimulates uptake and lysosomal degradation of $A \beta$ to reduce ISF $A \beta$ levels and attenuate amyloid plaque pathogenesis, in a mouse model of AD.

\section{Materials and Methods}

Reagents. A $\beta 1-42$ was purchased from American Peptide; FAM-A $\beta 42$ from AnaSpec; LysoTracker Red DND-99 from Invitrogen; and trifluoroacetic acid, 1,1,1,3,3,3-hexafluoro-2-propanol, bafilomycin A1, heparin, biotin-labeled transferrin, and Dynasore from Sigma.

A $\beta$ preparation. A $\beta 42$ was prepared as described previously (Hu et al., 2009). Briefly, dried peptide was pretreated with neat trifluoroacetic acid, distilled under nitrogen, washed with 1,1,1,3,3,3-hexafluoro-2propanol, distilled under nitrogen, and stored at $-20^{\circ} \mathrm{C}$. The peptide was diluted in DMSO to a final concentration of $200 \mu \mathrm{M}$. In this form, $\mathrm{A} \beta$ is in its monomeric form, but aggregates in culture medium (Gong et al., 2003 ) into oligomeric $A \beta$ species.

Primary astrocyte cultures. Murine cortical primary astrocytes were cultured from postnatal day 2 pups. Cortices were dissected from the brain, washed with HBSS, and treated with $0.25 \%$ trypsin/EDTA for 15 min at $37^{\circ} \mathrm{C}$. Following trypsin digestion, the tissue was resuspended and triturated in DMEM with 10\% FBS and $100 \mathrm{U} / \mathrm{ml}$ penicillin/streptomycin. The cell suspension was then plated into T-75 flasks coated with poly-D-lysine. The medium of the mixed glial cultures was changed every $3 \mathrm{~d}$. Once the cells reached confluence, they were shaken at $180 \mathrm{rpm}$ for 30 min to remove the microglial cells. The adherent cells were shaken at $240 \mathrm{rpm}$ for an additional $6 \mathrm{~h}$ to remove the oligodendrocyte precursor cells. The astrocyte-enriched cultures were then passed into 12-well plates for experiments.

Plasmid construction, cell transfection, and lentivirus transduction. Mouse TFEB cDNA containing an N-terminal-linked FLAG or Cerulean fluorophore was cloned into a pAAV vector containing the CMV promoter (pAAV-CMV-FLAG-TFEB). For specific expression of TFEB in astrocytes, a GFAP promoter (gfa2; Brenner et al., 1994) was used to drive TFEB expression in AAV vector (pAAV-GFAP-FLAG-TFEB) or lentiviral vector (LV-GFAP-FLAG-TFEB). C17.2 neural progenitor cells were transfected with pAAV-CMV-FLAG-TFEB or the control vectors using Lipofectamine 2000 (Invitrogen) for $48 \mathrm{~h}$ and harvested for further analysis. For transduction of lentiviral vectors in astrocytes, the virus was added to the cells (multiplicity of infection of 5) and incubated at $37^{\circ} \mathrm{C}$ for $48 \mathrm{~h}$. Fresh medium was then added and the cells were cultured for $8-10 \mathrm{~d}$ before performing experimental assays, changing the medium every $3 \mathrm{~d}$. We observed $>90 \%$ efficiency for transfection or transduction of exogenous TFEB (or GFP as control) in these in vitro studies.

Flow cytometry. C17.2 cells were incubated with LysoTracker Red (1 $\mu \mathrm{M})$ for $15 \mathrm{~min}$ and subjected to flow cytometry on FACScan instrument (Becton-Dickinson). Cyflogic software (CyFlo) was used to analyze 20,000 events per run.

$A \beta$ uptake and degradation. C17.2 cells were plated in 8-well chamber slides, and $500 \mathrm{~nm}$ FAM-A $\beta 42$ was added for $1-4 \mathrm{~h}$. The cells were stained with LysoTracker Red (100 nM) before confocal imaging. To quantify uptake, synthetic A $\beta 42$ ( $500 \mathrm{~nm}$ ) was applied to C17.2 cells and astrocytes for varying times. The cells were washed with PBS three times, trypsinized, and lysed in RIPA buffer. To quantify degradation, media containing A $\beta 42$ was removed and cells were thoroughly washed after $4 \mathrm{~h}$ incubation. At varying times after washing, the cells were trypsinized and lysed for ELISA. Bafilomycin A1 (100 nM) was added to the cells $30 \mathrm{~min}$ before harvest to inhibit lysosome acidification.

Transferrin internalization. Transferrin uptake assay was performed as described previously (Xiao et al., 2012). Briefly, primary astrocytes were cultured in serum-free medium for $2 \mathrm{~h}$, and then incubated with biotinylated transferrin $(20 \mu \mathrm{g} / \mathrm{ml})$ in serum-free medium for $5 \mathrm{~min}$ at $37^{\circ} \mathrm{C}$. Cells were placed on ice, washed with ice-cold PBS, and then subsequently incubated three times for $10 \mathrm{~min}$ on ice in $25 \mathrm{~mm} \mathrm{MesNa,} \mathrm{pH} \mathrm{5.0,}$ containing $150 \mathrm{~mm} \mathrm{NaCl}$ and $50 \mu \mathrm{M}$ deferoxamine mesylate to remove surface bound transferrin. Cell lysate was immunoblotted with anti-biotin antibody (Cell Signaling Technology) to detect internalized transferrin.

Dextran uptake assay. Primary astrocytes were incubated with $70 \mathrm{kDa}$ dextran-TMR conjugate $(10 \mu \mathrm{M})$ for the indicated duration. Thereafter, cells were washed thoroughly and trypsinized, followed by flow cytometric analysis with analysis of 20,000 events per run.

Animal model studies. B6C3-Tg (APPswe/PS1 $\Delta$ E9)85Dbo/Mmjax (also known as APP/PS1) transgenic mice, obtained from The Jackson Laboratory (Jankowsky et al., 2004), were injected with AAV8 viral particles (generated by the Hope Center Viral Core at Washington University), as described previously (Xiao et al., 2012). For plaque load studies, APP/PS1 mice were injected with $2 \mu$ of AAV8-GFAP-FLAG-TFEB or AAV8-GFAP-eGFP $\left(1.5 \times 10^{12}\right.$ viral particles/ml $)$ into bilateral hippocampi at 6 months of age. Mice were killed 4 months later. One hemisphere was fixed and coronal sections $(50 \mu \mathrm{m})$ were cut for histological analysis (X-34 staining and HJ3.4 immunostaining). The other hemisphere was immediately dissected, snap frozen on dry ice, and stored at $-80^{\circ} \mathrm{C}$ for biochemical analysis (ELISA and Western blot). To detect the $\mathrm{A} \beta$ level in predepositing mice, the abovementioned AAV viral vectors were injected into the hippocampi of APP/PS1 mice at 3 months of age, and the animals were killed 2 months later. All animal care and surgical procedures were approved by the Animal Studies Committee of Washington University School of Medicine in accordance with guidelines of the U.S. National Institutes of Health.

In vivo microdialysis. Two-month-old AAP/PS1 transgenic mice were transduced in the hippocampus with AAV8-GFAP-FLAG-TFEB and AAV8-GFAP-GFP particles, as above, and studied 4 weeks later by in vivo microdialysis, as previously described (Cirrito et al., 2003, 2011). Briefly, a guide cannula (BR-style; Bioanalytical Systems) was implanted and cemented with the tip at coordinates: bregma $-3.1 \mathrm{~mm}$, midline -2.5 $\mathrm{mm}, 1.2 \mathrm{~mm}$ below dura at a $12^{\circ}$ angle. A $2 \mathrm{~mm}$ microdialysis probe was then inserted into the hippocampus that contained a $38 \mathrm{kDa}$ MWCO semipermeable membrane (Bioanalytical Systems) allowing molecules smaller than this cutoff to diffuse into the probe. $A \beta$ capable of entering the probe is dubbed "exchangeable A $\beta$ " (Cirrito et al., 2003). The probe was flushed with $0.15 \%$ bovine serum albumin (Fisher Scientific) in an artificial CSF perfusion buffer at a constant rate $(1.0 \mu \mathrm{l} / \mathrm{min})$. The effluent was collected into a refrigerated fraction collector and assayed by sandwich ELISA for $\mathrm{A} \beta \mathrm{x}-40$ and $\mathrm{A} \beta \mathrm{x}-42$ peptides at the end of each experiment. All studies were initiated at the identical time of the day. During microdialysis, animals were housed in specially designed cages to permit free movement and ad libitum food and water while ISF A $\beta$ was being sampled. Baseline levels of ISF A $\beta$ were sampled every $90 \mathrm{~min}$ between hours 9 and 16 (after the microdialysis probe is inserted) and averaged to determine the "baseline ISF A $\beta$ level" in each mouse. Absolute in vivo concentration of ISF eA $\beta$ for each mouse was determined by correcting for the $20.8 \%$ recovery $(1.0 \mu \mathrm{l} / \mathrm{min})$ as obtained by the interpolated zero flow method as described previously (Menacherry et al., 1992; Cirrito et al., 2003). At hour $16(t=0)$, a $\gamma$-secretase inhibitor Compound E (200 nм reverse microdialysis; synthesized by AsisChem), was administered directly to the hippocampus by adding the drug to the microdialysis perfusion buffer. ISF $A \beta$ was then sampled every $60 \mathrm{~min}$ for an additional $6 \mathrm{~h}$. This enabled measurement of the elimination half-life of endogenous ISF A $\beta$ in vivo similar to (Cirrito et al., 2003).

Immunohistochemistry. Sections were incubated in $0.3 \% \mathrm{H}_{2} \mathrm{O}_{2}$ in Trisbuffered saline (TBS) for $10 \mathrm{~min}$, washed with TBS, blocked with 3\% dry milk in TBS-X $(0.25 \%$ Triton X-100 in TBS) for $1 \mathrm{~h}$, and incubated with HJ3.4 antibody (anti-A $\beta-1-13$; Roh et al., 2012) overnight. A solution 
from Vectastain ABC kit (1:400) was applied to brain slices for $1 \mathrm{~h}$, followed by $0.025 \% 3-3^{\prime}$ diaminobenzidine tetrachloride in $0.25 \% \mathrm{NiCl}$ and $0.05 \% \mathrm{H}_{2} \mathrm{O}_{2}$ for $10-15 \mathrm{~min}$. The slices were placed on glass slides, dried overnight, dehydrated, and mounted. Images were obtained with confocal microscope (Zeiss LSM).

$X-34$ plaque staining. Brain slices were mounted on SuperFrost Plus slides, permeabilized with $0.25 \%$ Triton X-100 for $30 \mathrm{~min}$, and stained with X-34 (a generous gift from Robert Mach, Washington University) dissolved in $40 \%$ ethanol and $60 \%$ water, $\mathrm{pH} \mathrm{10}$, for $20 \mathrm{~min}$. Tissue was then thoroughly rinsed in PBS and mounted with Fluoromount mounting media.

Plaque quantification. Brain sections $(50 \mu \mathrm{m})$ were collected every 300 $\mu \mathrm{m}$ from rostral anterior commissure to caudal hippocampus. Sections were stained with X-34 or immunostained with HJ3.4 antibodies $(n=10$ per group, 5 male and 5 female). Four slices per animal were used. NanoZoomer Digital Scanner (Hamamatsu Photonics) was used to create high-resolution digital images of the stained brain slices. The total area of plaque coverage in the hippocampus or piriform cortex (devoid of viral transduction) was measured using NIH ImageJ software and expressed as percentage total area for each slice. Results from $n=4$ sections were averaged to represent each animal.

Immunofluorescence. Fixed cells or paraffin-embedded brain sections were washed with PBS, permeabilized with $0.3 \%$ Triton X-100 in PBS for $20 \mathrm{~min}$, and blocked. For double labeling, a mixture of the following antibodies was used: rabbit anti-FLAG (Sigma; 1:500), rat anti-LAMP1 (Santa Cruz Biotechnology; 1:50), mouse anti-TFEB (MyBioSource; 1:50), rabbit anti-TFEB (Bethyl Laboratories; 1:100), rabbit anti-GFAP (Sigma; 1:100), rabbit anti- Ibal (Wako Chemicals; 1:1000), and mouse anti-NeuN (Sigma; 1:1000). A secondary antibody mixture of Alexa Fluor 488-conjugated goat anti-rabbit IgG and Alexa Fluor 594conjugated goat anti-rat IgG (Invitrogen), or Cy3-conjugated donkey anti-rabbit IgG (Jackson ImmunoResearch) and Alexa Fluor 488conjugated donkey anti-mouse IgG (Invitrogen) was applied. Cells or sections were examined by confocal microscope (Zeiss LSM).

Stereological analysis. The sections were stained with $0.05 \%$ cresyl violet solution. The total neuron number in CA1 stratum pyramidale ( $\mathrm{sp}$ ) and CA3 sp in the dorsal hippocampus was assessed using a computerbased stereology system (Stereo Investigator; MicroBrightField). Neuron numbers were estimated with the optical fractionator (West et al., 1991). Cresyl violet-stained cells were counted in four equally spaced $50 \mu \mathrm{m}$ sections in the dorsal hippocampus of CA1 sp and CA3 sp, respectively. Cresyl violet stained cells with nuclei imaged within the inclusive zone of each dissector frame were counted. Results were reported in units of density (cells per $\mathrm{mm}^{3}$ ).

$A \beta$ ELISA. $\mathrm{A} \beta$ in cell lysates from transfected C17.2 cells and transduced astrocytes were detected by sandwich ELISA, as previously described (Verges et al., 2011). To detect total A $\beta$ in the hippocampus in 5 -month-old mice, dissected tissue was sequentially homogenized in PBS followed by RIPA buffer ( $50 \mathrm{~mm}$ Tris- $\mathrm{HCl}, 150 \mathrm{~mm} \mathrm{NaCl}, 1 \%$ Triton $\mathrm{X}-100,0.5 \%$ deoxycholate, $0.1 \%$ SDS, and $1 \times$ protease inhibitor cocktail, to obtain detergent soluble $\mathrm{A} \beta$ at an age when plaques are not observed; Yan et al., 2009), and samples were pooled for analysis. In aged mice (10 months old, when plaques are abundant), hippocampal tissues were sequentially homogenized in PBS followed by $5 \mathrm{~m}$ guanidine in TBS, $\mathrm{pH} 8.0$ (to extract fibrillar and membrane bound $\mathrm{A} \beta$ ). For ELISA assays, $\mathrm{A} \beta \mathrm{X}-40$ and $\mathrm{A} \beta \mathrm{x}-42$ peptides were captured with mouse monoclonalcoating antibodies HJ2 (anti-A $\beta 35-40$ ) and HJ7.4 (anti-A $\beta 37-42$ ) or HJ5.1 (anti-A $\beta 13-28$ ), respectively (Kim et al., 2009). HJ5.1 (antiA $\beta 13-28)$, a biotinylated antibody targeting the central domain, and HJ3.5 (anti-A $\beta 1-13$, provided by Dr. David Holtzman, Washington University School of Medicine, St. Louis, MO), which targets the $\mathrm{N}$-terminal amino acids, were used as the detecting antibody, followed by streptavidin-poly-HRP-40 (Fitzgerald Industries). All ELISA assays were developed using Super Slow ELISA TMB (Sigma) and absorbance read on a Bio-Tek Epoch plate reader at $650 \mathrm{~nm}$. Standard curves were generated from synthetic human $\mathrm{A} \beta 1-40$ or $\mathrm{A} \beta 1-42$ peptides (American Peptide).

Quantitative PCR. Real-time PCR was performed as described previously (Ma et al., 2012). Briefly, total RNA was prepared from transfected
Table 1. Primer sequences employed for quantitative PCR analysis for indicated murine genes

\begin{tabular}{|c|c|c|}
\hline Gene & Forward $\left(5^{\prime}-3^{\prime}\right)$ & Reverse $\left(5^{\prime}-3^{\prime}\right)$ \\
\hline LAMP1 & ACATCAGCCCAAATGACACA & GGCTAGAGCTGGCATTCATC \\
\hline CATHB & AAATCAGGAGTATACAAGCATGA & GCCCAGGGATGCGGATGG \\
\hline CATHD & CTGAGTGGCTTCATGGGAAT & CCTGACAGTGGAGAAGGAGC \\
\hline ADAM17 & AGGACGTAATTGAGCGATTTTGG & TGTTATCTGCCAGAAACTTCCC \\
\hline ADAM10 & GTGCCAAACGAGCAGTCTCA & ATTCGTAGGTTGAACTGTCTTCC \\
\hline BACE1 & CAGTGGGACCACCAACCTTC & GCTGCCTTGATGGACTTGAC \\
\hline PSEN1 & TGCACCTTTGTCCTACTTCCA & GCTCAGGGTTGTCAAGTCTCTG \\
\hline PEN2 & ATCTTGGTGGATTTGGGTTCC & GCGCCAAACATAGCCTTTGATTT \\
\hline$L D L R$ & CGCGGATCTGATGCGTCGCT & CGGCCCTGGCAGTTCTGTGG \\
\hline LRP1 & AACCCCTGCAGTGTCAACAA & GGAGCGAGTCGTCTCTGATG \\
\hline$A P O E$ & CTGACAGGATGCCTAGCCG & CGCAGGTAATCCCAGAAGC \\
\hline APOJ & GCCAGTGTGAAAAGTGCCAG & GTTAGCCTGGGCAGGATTGT \\
\hline MMP2 & CCTGGACCCTGAAACCGTG & TCCCCATCATGGATTCGAGAA \\
\hline MMP9 & GGACCCGAAGCGGACATTG & GAAGGGATACCCGTCTCCGT \\
\hline$I D E$ & TAATCCGGCCATCCAGAGAAT & CCAGCTCTAGTCCACGGTATT \\
\hline NEP & GGCCTCCCTTCCAGAGACTA & ACGAATCAGTCTGGCCACAG \\
\hline GAPDH & АСТСССАСТСТTССАССТTC & TCTTGCTCAGTGTCCTTGC \\
\hline
\end{tabular}

C17.2 cells or AAV-transduced hippocampus using an RNA-easy mini kit (Qiagen), and cDNA was synthesized with $1 \mu \mathrm{g}$ of total RNA using SuperScript III first-strand synthesis system (Invitrogen). One microliter of cDNA template was mixed with $12.5 \mu \mathrm{l}$ of $2 \times$ SYBR Green PCR Master Mix (Invitrogen) and subjected to quantitative PCR in triplicate under the following conditions: $50^{\circ} \mathrm{C}, 2 \mathrm{~min} ; 95^{\circ} \mathrm{C}, 10 \mathrm{~min}$; followed by 40 cycles of $95^{\circ} \mathrm{C}, 15 \mathrm{~s} ; 60^{\circ} \mathrm{C}, 1 \mathrm{~min}$ in the ABI7500 Fast RealTime PCR system. The housekeeping gene GAPDH was also amplified in parallel as a reference for the quantification of transcripts. Primer sequences used are shown in Table 1).

Cathepsin assay. Cathepsin activity was measured as described previously (Baldo et al., 2011) with slight modifications. Cell pellets or brain tissues were homogenized in $100 \mathrm{~mm}$ sodium acetate, $\mathrm{pH} 5.5$, with 2.5 mM EDTA, $0.01 \%$ Triton X-100, and $2.5 \mathrm{~mm}$ DTT. For the Cathepsin B assay, the supernatant was incubated with $100 \mu \mathrm{M}$ Z-Arg-Arg-AMC (Bachem) at $\mathrm{pH}$ 6.0. The fluorescent intensity of the cleavage product was determined by excitation at $355 \mathrm{~nm}$ and emission at $460 \mathrm{~nm}$ using kinetic readings in a TECAN Infinite M200 Pro microplate reader (Tecan), and comparison was performed with a standard (7-amino-4methylcoumarin, AMC; AnaSpec). The Cathepsin D assay was performed at $\mathrm{pH} 4.0$ by incubating the supernatant with $10 \mu \mathrm{M}$ substrate 7-methoxycoumarin-4-acetyl (Mca)-Gly-Lys-Pro-Ile-Leu-Phe-Phe-ArgLeu-Lys-2,4 nitrophenyl (Dnp)-D-Arg- $\mathrm{NH}_{2}$, with Mca-Pro-Leu-OH (Enzo Life Sciences) as the standard; fluorescent intensity was determined with 320 $\mathrm{nm}$ excitation at $420 \mathrm{~nm}$ emission using the microplate reader.

Immunoblotting. Protein samples were run on $4-12 \%$ Bis-Tris gels. Blots were probed with the following antibodies: FLAG (1:1000), TFEB (1:500), LAMP1 (1:500), Cathepsin B (Abcam; 1:500), Cathepsin D (Santa Cruz Biotechnology; 1:200), low-density lipoprotein receptor (LDLR; Novus; 1:500), LDL-receptor related peptide-1 (LRP1; Abcam; 1:500), and Actin (Sigma; 1:2000). Normalized band intensity was quantified using ImageJ software.

Statistical analysis. All data are shown as mean \pm SEM. Data were analyzed by two-tailed Student's $t$ test for detecting significant differences between two groups. Differences among groups were analyzed by one-way ANOVA followed by post hoc Tukey's test. Differences were deemed statistically significant at ${ }^{*} p<0.05$ and ${ }^{\star *} p<0.01$.

\section{Results}

Exogenous TFEB expression stimulates lysosome biogenesis in neural cells, in vitro

Astrocytes take up $\mathrm{A} \beta$ and amyloid material for lysosomal degradation (Wyss-Coray et al., 2003; Koistinaho et al., 2004; Basak et al., 2012), but age-related lysosome dysfunction is suspected to underlie $\mathrm{A} \beta$ accumulation within astrocytes in elderly individuals (Funato et al., 1998) and in patients with AD (Nagele et al., 
A

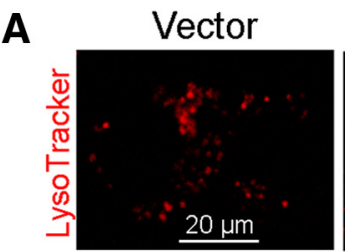

B

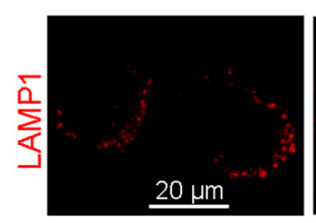

D

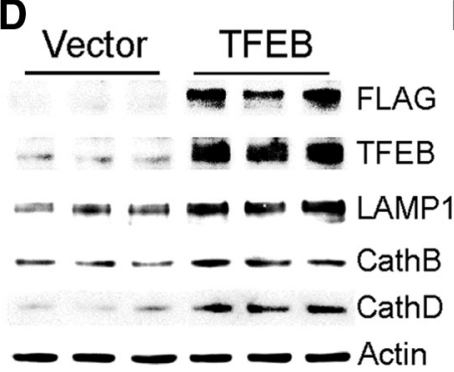

TFEB
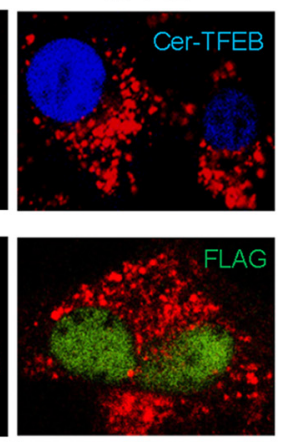

E
C

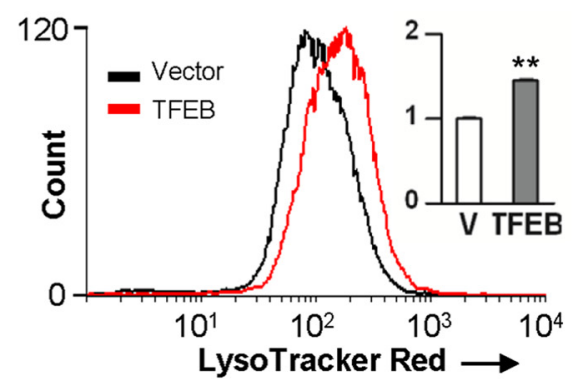

F
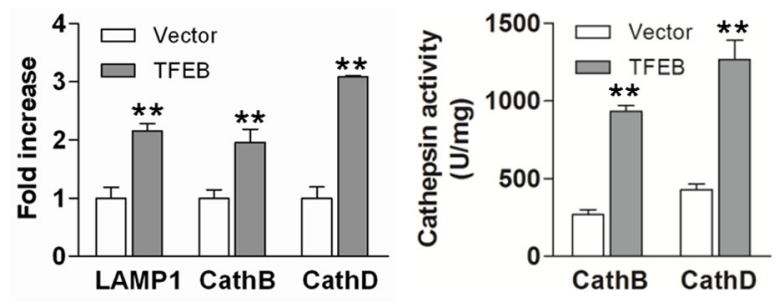

Figure 1. TFEB stimulates lysosome biogenesis and function. $A$, Representative confocal images demonstrating LysoTracker Red expression in Cerulean-tagged TFEB-transfected (Cer-TFEB) C17.2 cells versus empty vector transfected controls. Representative of $n=4$ independent experiments. B, Representative confocal images demonstrating LAMP1 expression in C17.2 cells transfected with FLAG-tagged TFEB versus empty vector transfected controls. Representative of $n=4$ experiments. C, Flow cytometric analysis of LysoTracker Red staining in cells transfected with FLAG-tagged TFEB or empty vector (V; as control), with quantification of mean fluorescence expressed as fold over control (inset). $N=3 /$ group. $\boldsymbol{D}, \boldsymbol{E}$, Immunoblots $(\boldsymbol{D})$ and quantification (E) of LAMP1 and Cathepsin B and D expression in cells transfected as in C. F, Cathepsin B and D activity in cells transfected as in $C . N=4 /$ group; ${ }^{* *} p<0.01$.

2003). TFEB, a recently described basic helix-loop-helix transcriptional activator, stimulates lysosome biogenesis with activation of lysosomal degradative pathways (Sardiello et al., 2009; Settembre et al., 2011, 2013b; Roczniak-Ferguson et al., 2012), and cellular trafficking pathways (Medina et al., 2011; PeñaLlopis et al., 2011). Accordingly, we tested the hypothesis that enhancing lysosomal degradative pathways in astrocytes by exogenous expression of TFEB will counter amyloid pathogenesis. To confirm that TFEB stimulates lysosome biogenesis and function in neural cells, we exogenously expressed murine TFEB in a mouse neural progenitor C17.2 cell line (which can transdifferentiate into astrocytes; Zang et al., 2008), and examined lysosome abundance, and expression and function of Cathepsin B and D, which are two lysosomal enzymes implicated in $A \beta$ catabolism and AD pathogenesis (Sun et al., 2008; Butler et al., 2011; Schuur et al., 2011; Yang et al., 2011; Avrahami et al., 2013). Exogenously expressed Cerulean-tagged (Fig. 1A) or FLAG-tagged TFEB (Fig. $1 B$ ) localized to the nucleus indicating that it was transcriptionally active (Sardiello et al., 2009; Settembre et al., 2012) with an increase in abundance of acidic organelles stained with LysoTracker Red (Fig. $1 A, C$ ) or lysosome membrane protein, LAMP1 (Fig. 1B), indicating stimulation of lysosome biogenesis compared with the nontransfected cells. Exogenous expression of TFEB also resulted in transcriptional upregulation of lysosomal genes, LAMP1 and Cathepsin B and D (by 21, 26, and 34\%, respectively, over vector control; $n=4$ /group, $p<0.05$ ). This was associated with $>6$-fold increase in TFEB protein expression ( $p<0.01, n=3$ /group), and a 2 - to 3 -fold increase in expression of LAMP1, Cathepsin B, and Cathepsin D proteins (Fig. 1D,E). An $\sim 3$-fold increase in Cathepsin B and D activity was observed in TFEB transfected cells compared with controls (Fig. $1 F$ ). Collectively, these results confirm that exogenous TFEB transcrip- tionally upregulates lysosome abundance and stimulates activity of lysosomal enzymes, in vitro.

\section{Exogenous TFEB expression enhances $A \beta$ uptake and degradation}

To determine the effect of TFEB on the kinetics of $A \beta$ uptake and its subcellular localization, C17.2 cells were transfected with TFEB or empty vector and incubated with 500 nM FAM-labeled $\mathrm{A} \beta 42$ for increasing periods of time $(1,2$, and $4 \mathrm{~h})$ at $37^{\circ} \mathrm{C}$. At these time points, cells were imaged using confocal microscopy with colabeling for LysoTracker Red, which is selectively taken up in acidic vesicles, i.e., late endosomes and lysosomes (Sardiello et al., 2009). Punctate intracellular $A \beta$ was first apparent within $1 \mathrm{~h}$, and progressively increased thereafter (Fig. $2 A$ ), indicating that FAM-A $\beta 42$ uptake was time dependent. Importantly, all intracellular FAM-A $\beta 42$ eventually localized to LysoTracker-stained vesicles, suggesting that $A \beta$ is taken up and trafficked into lysosomes. Notably, TFEB enhanced A $\beta$ uptake with increased colocalization of $\mathrm{A} \beta$ with LysoTracker-stained organelles at all the time points examined. To confirm these observations, we measured intracellular $\mathrm{A} \beta$ levels in $\mathrm{C} 17.2$ cells transfected with TFEB or empty vector for $48 \mathrm{~h}$, after application of $\mathrm{A} \beta 42(500 \mathrm{nM})$ for increasing periods of time $(1,2,4$, and $8 \mathrm{~h})$. The cells were thoroughly washed and trypsinized to digest surface-bound $\mathrm{A} \beta$, followed by lysis, and intracellular A $\beta 42$ was quantified with ELISA. Immunodetectable levels of intracellular $A \beta$ levels progressively increased in control transfected cells (Fig. $2 B$ ), as imaged above (Fig. 2A). TFEB-transfected cells demonstrated significantly higher levels of intracellular $A \beta 42$ compared with controls (Fig. $2 B$ ), suggesting faster rates of $A \beta$ internalization. We next determined whether TFEB affects intracellular $A \beta$ degradation. The cells were incubated with $\mathrm{A} \beta 42$ for $4 \mathrm{~h}$ and then thoroughly 
A
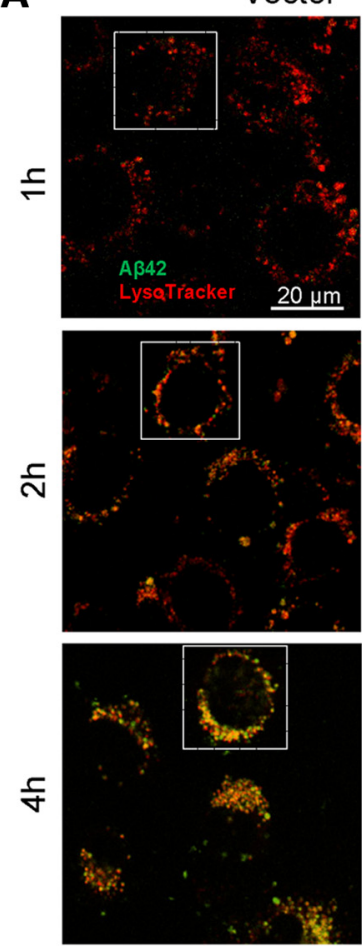

B

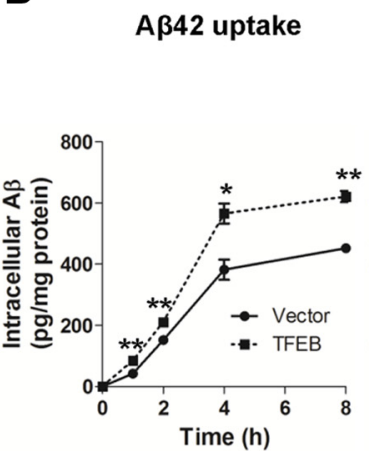

C

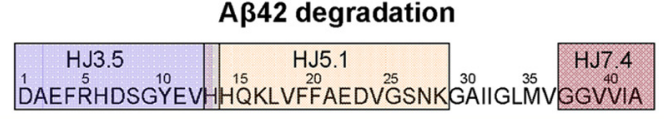

TFEB
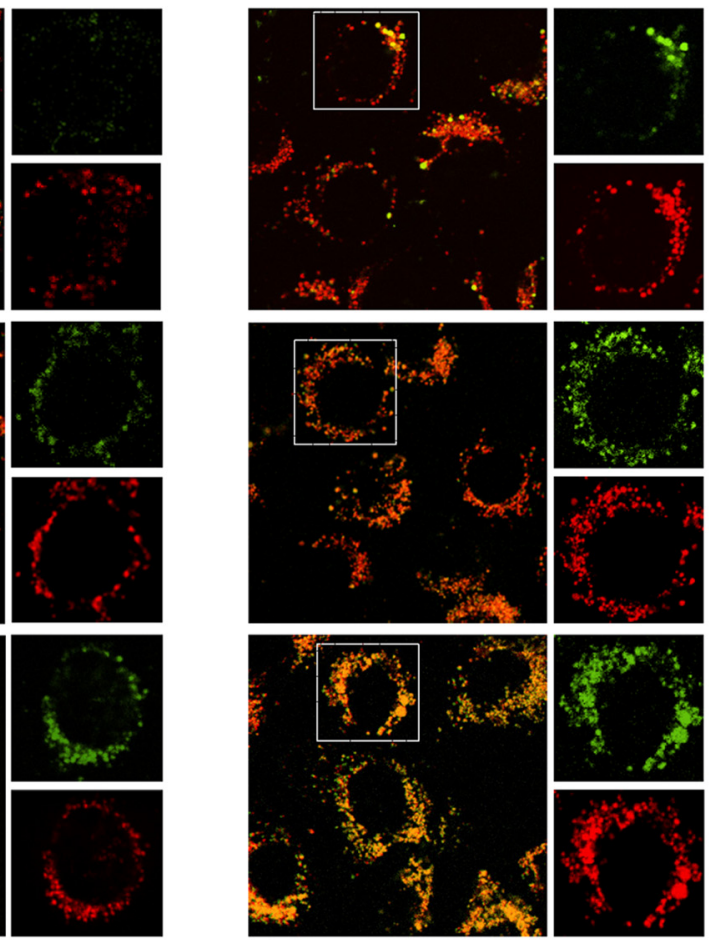

D Effect of Bafilomycin
on $A \beta 42$ degradation
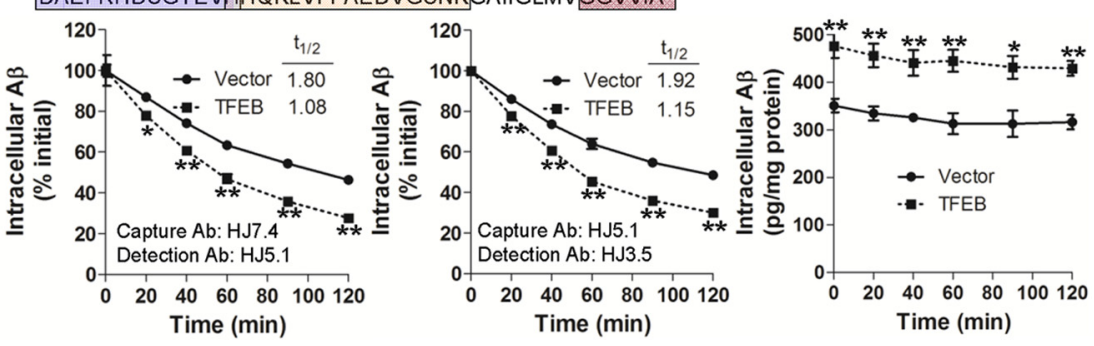

Figure 2. TFEB enhances $A \beta$ uptake and degradation in C17.2 cells. $A$, Representative confocal images of $C 17.2$ cells transfected with TFEB or empty vector, and incubated with $500 \mathrm{~nm} F A M-A \beta 42$ at varying times, as indicated and imaged with LysoTracker Red colabeling. Representative of $n=3$ independent experiments. B, C17.2 cells were transfected with TFEB or empty vector for $48 \mathrm{~h}$, and subsequently incubated with $A \beta 42(500 \mathrm{~nm})$ for an additional $1-8 \mathrm{~h}$, and intracellular $\mathrm{A} \beta 42$ was analyzed by ELISA at the time points indicated. $N=3 / \mathrm{group}$ per time point. $C$, $C 17.2$ cells were transfected with TFEB or empty vector for $48 \mathrm{~h}$ and $A \beta 42(500 \mathrm{~nm}$ ) was applied for $4 \mathrm{~h}$, followed by its removal. (ells were then thoroughly washed. At varying times after washing (as indicated), the cells were trypsinized, lysed, and intracellular A $\beta 42$ was quantified by ELISA using two separate strategies. Specific antibodies used (refer to schematic, top) are noted (bottom). $N=3 /$ group per time point. $D$, Cells treated as in C with the addition of Bafilomycin A1 (100 nM) for $30 \mathrm{~min}$ before washing out the $A \beta$ and cultured in its presence until the cells were collected for assay. $N=4 / \mathrm{group}$; ${ }^{*} p<0.05,{ }^{* *} p<0.01$.

washed. At varying times thereafter, the cells were trypsinized (to digest surface-bound $\mathrm{A} \beta$ ) and lysed for assessment of intracellular $A \beta$ levels. Our results demonstrate that the rate of decline of intracellular $A \beta$ levels was significantly enhanced by TFEB expression compared with controls (Fig. 2C). This was reflected in the shortened half-life $\left(t_{(1 / 2)}\right)$ in TFEB-transfected cells, and confirmed with an alternate $A \beta$ peptide capture and detection strategy using distinct epitopes. These data suggest that TFEB enhances both the uptake and complete degradation of $A \beta$. To determine whether TFEB-mediated elimination of $A \beta$ proceeded via lysosomal degradation, we cultured cells in the presence of Bafilomycin A1, a proton pump inhibitor that blocks lysosome acidification and impairs function (Yamamoto et al., 1998; Mousavi et al., 2001), beginning 30 min before removal of $A \beta 42$ from the medium. Bafilomycin A1 treatment largely prevented the decline in intracellular $A \beta 42$ levels (Fig. 2D), to the same extent in both TFEB-transfected and control cells. These data indicate that clearance of intracellular $A \beta$ requires normal lysosome function, and TFEB enhances $A \beta$ removal via stimulating lysosomal function.

Recent studies have ascribed a prominent role for receptormediated uptake of $A \beta$ via LDLR (Basak et al., 2012) and LRP1 (Kanekiyo et al., 2011; Verghese et al., 2013), as well as via macropinocytosis, a heparan sulfate proteoglycan-mediated process (Kanekiyo et al., 2011). Therefore, to confirm whether TFEB accelerates $\mathrm{A} \beta$ uptake and degradation in astrocytes and to examine the mechanisms involved, we lentivirally transduced primary murine astrocytes with TFEB or GFP (as control) and examined intracellular $\mathrm{A} \beta$ after incubation with $\mathrm{A} \beta 42$ for $4 \mathrm{~h}$ in the presence of Dynasore (a dynamin-specific inhibitor of endocytosis), 
A

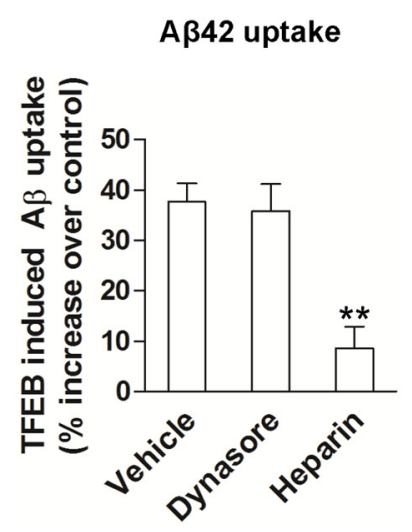

D A A 42 degradation

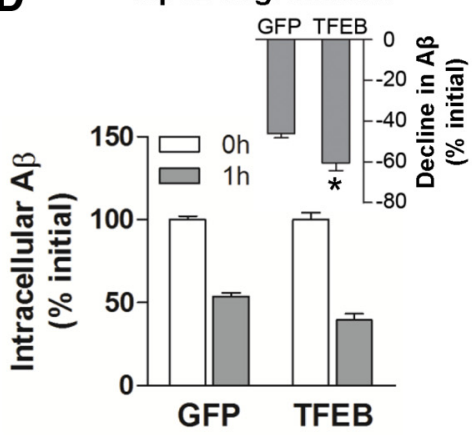

B
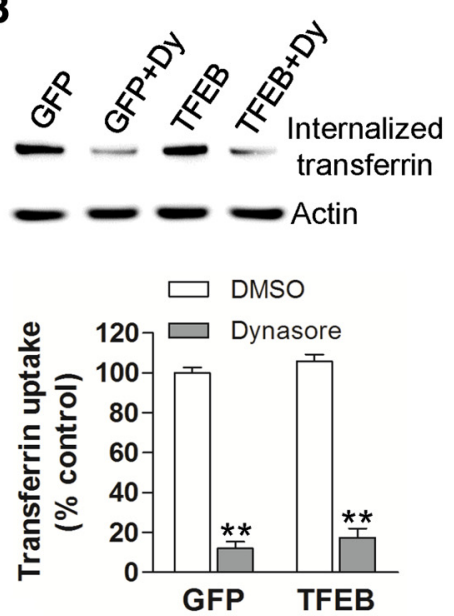

$\mathbf{E}$

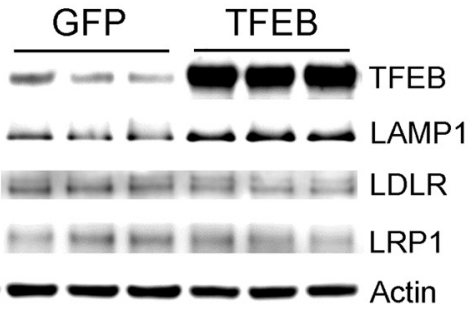

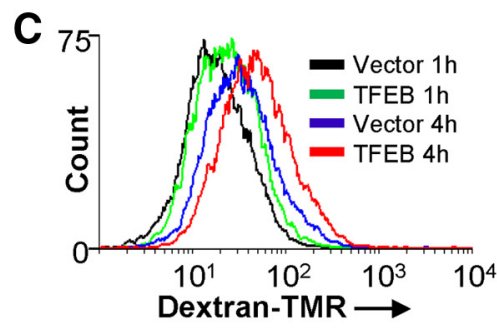

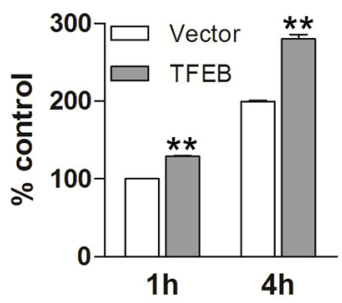

$\mathbf{F}$

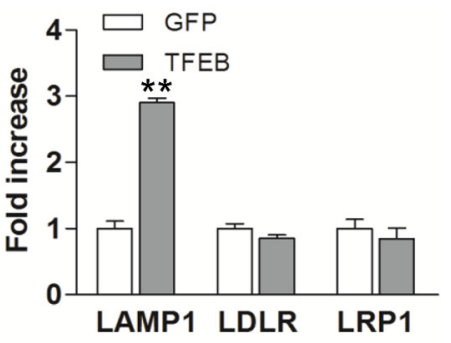

Figure 3. TFEB stimulates $A \beta$ uptake and degradation in primary astrocytes. $A$, Percentage increase in $A \beta$ uptake over a duration of $4 \mathrm{~h}$ in primary astrocytes transduced with TFEB over those transduced with GFP (as control), in the presence of Dynasore $(100 \mu \mathrm{M})$, heparin $(100 \mu \mathrm{g} / \mathrm{ml} ; \sim 18 \mathrm{U} / \mathrm{ml})$, and vehicle (as control). $N=3$ experiments. $\boldsymbol{B}$, Transferrin uptake in primary astrocytes transduced with TFEB or GFP (as control). $N=3 /$ group. Dy, Dynasore. C, Flow cytometric analysis with representative tracings (top) and quantitation of mean fluorescence (bottom) for $70 \mathrm{kDa}$ dextran-TMR uptake in primary astrocytes transduced with TFEB or empty vector (as control) for the indicated duration. $N=4$ /group. D, Primary astrocytes were transduced with TFEB or GFP (as control) and incubated with $A \beta$ for $4 \mathrm{~h}$, followed by washing and trypsinization. Intracellular $A \beta$ levels were measured thereafter at $T$ (time) $=0$ and $1 \mathrm{~h}$. Inset shows percentage reduction in $A \beta$ levels over this duration. $N=3$ experiments. $E, F$, Immunoblot and quantitation of LAMP1, LRP1, and LDLR expression in TFEB-transduced versus GFP-transduced primary astrocytes. $N=3 /$ group; ${ }^{*} p<0.05,{ }^{* *} p<0.01$.

heparin (to antagonize heparan sulfate proteoglycans), or diluent as control. As shown in Figure 3A, TFEB expression $(\sim 9$-fold over control; Fig. $3 E$ ) resulted in significantly increased intracellular $\mathrm{A} \beta$ levels compared with control transduced cells. This increase was not affected by Dynasore treatment, but was significantly attenuated by heparin. Consistent with this observation, we found that TFEB transduction did not upregulate transferrinreceptor endocytosis (which was inhibited by Dynasore treatment; Fig. $3 B$ ), but significantly upregulated the internalization of $70 \mathrm{kDa}$ dextran (Fig. 3C), which is known to occur via fluidphase macropinocytosis (Fan et al., 2007). Additionally, as observed with C17.2 cells (Fig. 2B), TFEB transduction accelerated the decline in intracellular $A \beta$ in primary astrocytes (Fig. 3D). Consistent with the observation of a lack of effect of TFEB on endocytosis of $A \beta$, we did not detect TFEBbinding CLEAR sites (Palmieri et al., 2011) in the promoters of murine LDLR and LRP1, and TFEB did not affect their transcript levels (data not shown) or protein abundance (Fig. $3 E, F)$. Importantly, TFEB induced upregulation of lysosomal protein, LAMP1, in astrocytes indicating increased lysosomal biogenesis, as observed in C17.2 cells (see above). These data suggest that TFEB may accelerate $\mathrm{A} \beta$ uptake via heparan sulfate proteoglycan binding and macropinocytosis (Mandrekar et al., 2009; Holmes et al., 2013).
AAV-mediated TFEB transduction in astrocytes induces lysosome biogenesis and upregulates Cathepsin activity, in vivo

Given the in vitro demonstration of TFEB-mediated enhancement of $\mathrm{A} \beta$ uptake and lysosomal degradation, we examined whether enhancing the cellular degradative capacity of astrocytes, in vivo, may be an effective strategy to reduce ISF $A \beta$ levels and attenuate plaque pathogenesis in $\mathrm{AD}$. Indeed, astrocytes demonstrate intracellular accumulation of $\mathrm{A} \beta$-immunoreactive material in mouse models of $\mathrm{AD}$, which may reflect a failure of catabolism (Wyss-Coray et al., 2003). Enhancement of lysosomal degradative capacity by exogenous TFEB expression may correct this underlying defect, as was observed with diverse conditions of lysosome dysfunction (Settembre et al., 2013a). To test this premise, we used a viral gene transfer approach to target TFEB expression to astrocytes in the hippocampus of 6-month-old APP/PS1 mice, at a stage of early plaque deposition and growth (Yan et al., 2009). N-terminal FLAG- tagged murine TFEB was packaged in an AAV8 vector driven by a human GFAP promoter, which was highly efficacious and specific in targeting astrocytes in our previous studies (Kraft et al., 2013). AAV8 carrying a GFAP promoter driving eGFP served as control. The viral particles were stereotactically injected into bilateral hippocampi of 6-monthold APP/PS1 mice. The hippocampus was chosen for viral target- 

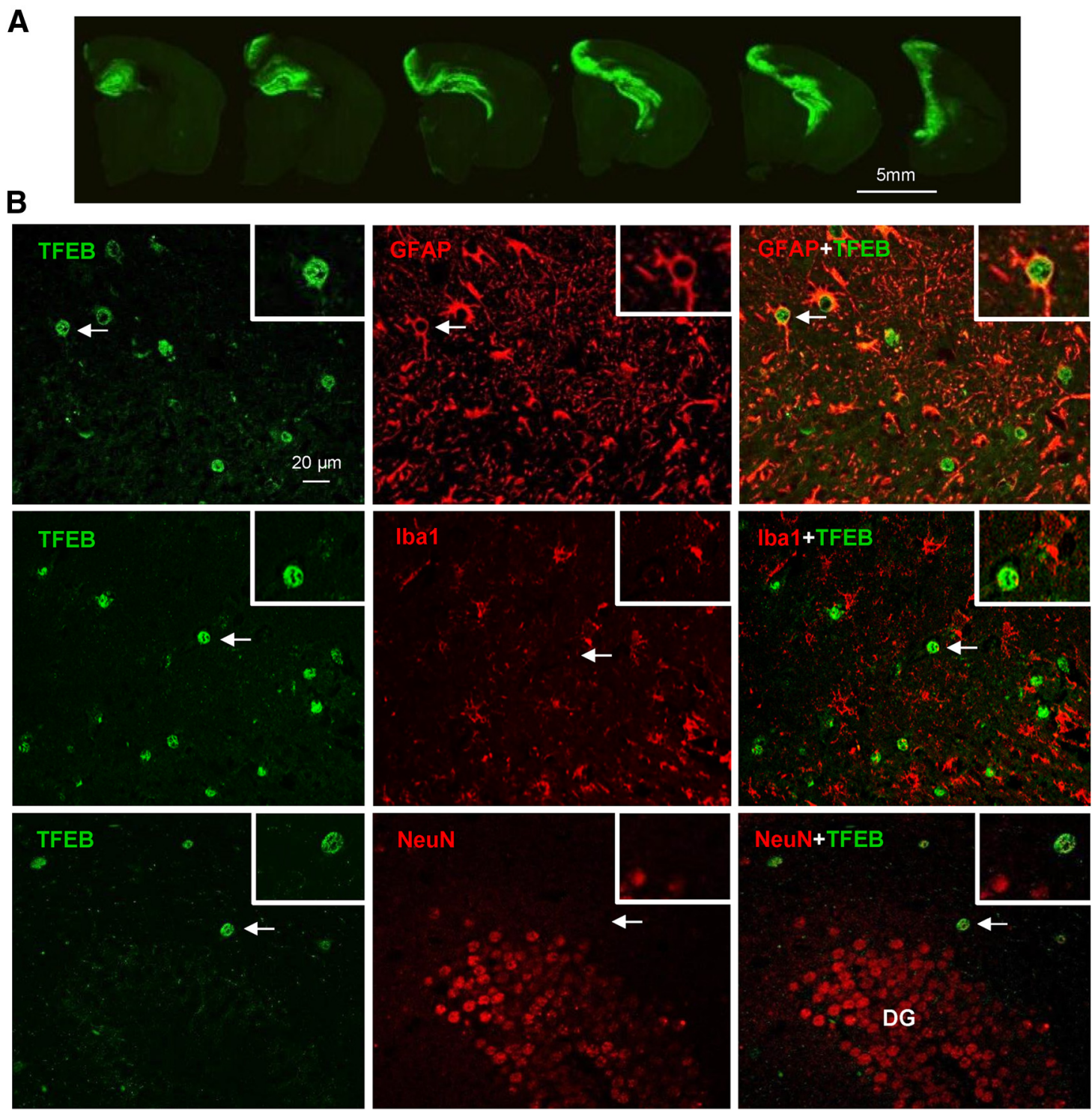

C

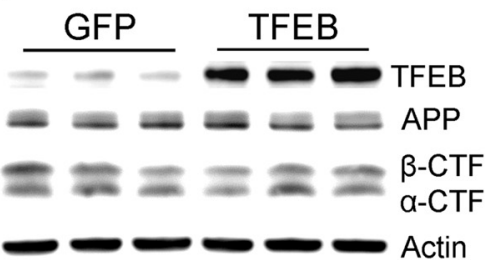

D

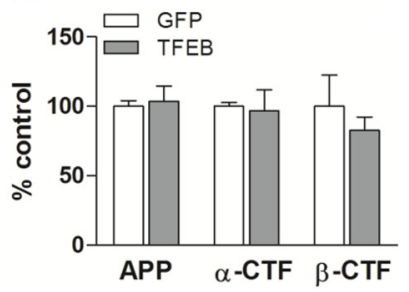

\section{$\mathbf{E}$}

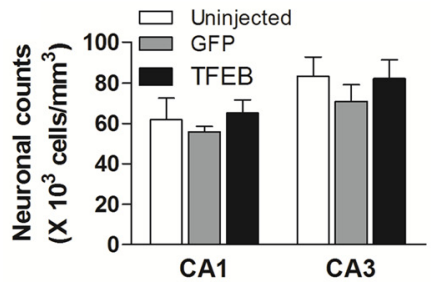

Figure 4. AAV8-mediated gene transfer of GFAP-promoter driven TFEB targets expression specifically to astrocytes. $A$, Representative fluorescence images of GFP expression in the hippocampus of APP/PS1 mice injected with AAV8-GFAP-eGFP viral particles. Sequential images of brain sections confirm high transduction efficiency throughout the anterior hippocampus. $\boldsymbol{B}$, Representative confocal images demonstrating expression of TFEB (green) with GFAP (red, top), Iba-1 (red, middle), and NeuN (red, bottom) in the hippocampus of APP/PS1 mice injected with AAV8-GFAP-FLAGTFEB particles, demonstrating astrocyte-specific expression of TFEB. The boxed inserts (upper right corner) demonstrate magnified images of individual TFEB-labeled cells (arrows). DG, dentate gyrus. C, D, Immunoblot and quantitation of APP, $\alpha$-CTF, and $\beta$-CTF in AAV8-GFAP-FLAG-TFEB and AAV8-GFAP-eGFP transduced hippocampi. $N=3 /$ group. $E$, Neuronal counts in the CA1 and CA3 layers of the hippocampi from AAV8-GFAP-FLAG-TFEB and AAV8-GFAP-eGFP transduced APP/PS1 mice and uninjected age- and sex-matched APP/PS1 mice as controls. $N=4 /$ group.

ing because of its easily accessible location and its characteristic and representative deposition of amyloid plaques (Yan et al., 2009). Four months after injection (at 10 months of age), mice were killed and assessed for efficacy of viral gene transfer. In control brains, GFP was observed throughout the anterior hippocampus, spanning 3-4 $\mathrm{mm}$ in the AP direction (Fig. $4 A$ ). The FLAG-TFEB construct was selectively transduced to astrocytes in the hippocampus, as assessed by colocalization of TFEB and
GFAP within cells demonstrating characteristic astrocytic morphology (Fig. 4B). Exogenous TFEB did not colocalize with Iba-1 (a microglial protein) or NeuN (a neuronal marker) demonstrating specificity of the targeting strategy (Fig. $4 B$ ). Consistent with the lack of neuronal transduction, we did not observe alterations in abundance of APP, its $\alpha$-C-terminal fragment ( $\alpha$-CTF), or the $\beta$-C-terminal fragment $(\beta$-CTF), and no changes in transcript levels coding for $\mathrm{A} \beta$ processing enzymes (ADAM17, ADAM10, 
A
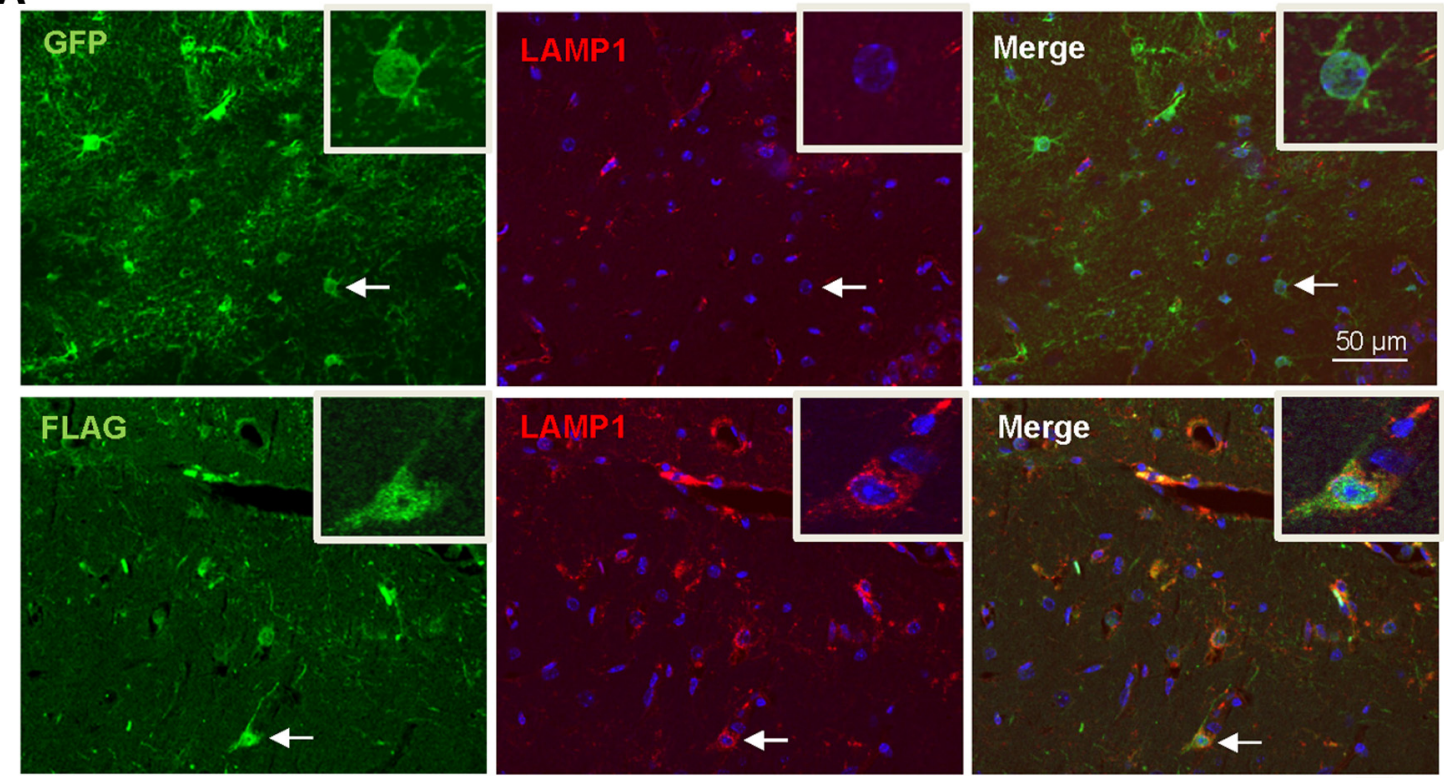

B

\section{C}
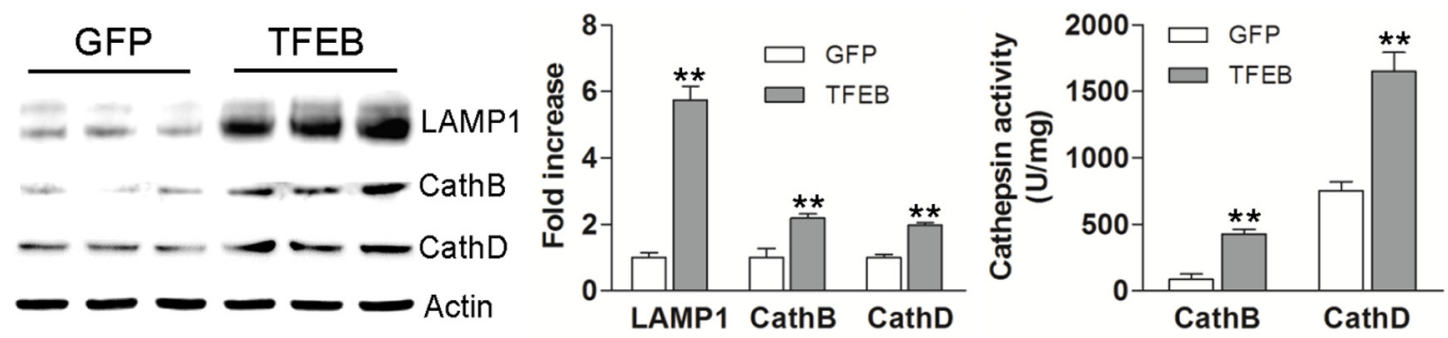

Figure 5. AAV8-mediated astrocytic gene transfer of TFEB in astrocytes promotes lysosome biogenesis in APP/PS1 mice. $\boldsymbol{A}$, Representative confocal images demonstrating expression of FLAG (green) and LAMP1 (red) in hippocampal tissues transduced with AAV8-GFAP-FLAG-TFEB (bottom) and AAV8-GFAP-eGFP (top) viral particles. Arrow indicates individual double-labeled cell shown under high magnification (insert, right upper corner). $\boldsymbol{B}, \boldsymbol{C}$, Immunoblots $(\boldsymbol{B})$ with quantification $(\boldsymbol{C})$ of lysosomal proteins in extracts from hippocampi transduced with AAV8-GFAP-FLAG-TFEB or AAV8-GFAP-eGFP. $N=3$ /group. D, Cathepsin B and D activity in extracts from hippocampi transduced with AAV8-GFAP-FLAG-TFEB or AAV8-GFAP-eGFP. $N=4$ /group; ${ }^{* *} p<0.01$.

BACE, PSEN1, and PEN2; data not shown) in AAV8-GFAPFLAG-TFEB transduced mice, compared with control. This indicates a lack of effect of TFEB expression on APP processing (Fig. 4C,D). Additionally, we did not observe a difference in neuronal counts in the hippocampus between TFEBtransduced, GFP-transduced, and uninjected APP/PS1 mice (Fig. 4E). These data demonstrate a lack of toxicity with AAVmediated TFEB or GFP transduction strategy and the lack of neuronal pathology in this mouse model of AD (APP/PS1 mice) at 10 months of age.

Exogenous TFEB localized to the nucleus of transduced astrocytes (Fig. 5A), indicating that it was transcriptionally "active" (Settembre et al., 2011; Roczniak-Ferguson et al., 2012). AAVmediated transduction of TFEB resulted in a sixfold increase in TFEB expression compared with controls $(p<0.01, n=$ 3/group; Fig. 5B), and increased LAMP1 expression (Fig. 5A-C), consistent with stimulation of lysosome biogenesis, as observed in vitro (Figs. $1 A-E ; 3 C, D$ ). Immunoblotting of hippocampal extracts confirmed a sixfold increase in LAMP1 and a twofold increase in Cathepsin B and D compared with controls (Fig. $5 B, C$ ). TFEB expression resulted in a dramatic increase of Cathepsin $B$ and $\mathrm{D}$ activity (Fig. 5D), indicating that exogenous TFEB stimulates lysosome function, in vivo.

\section{Astrocytic TFEB expression reduces brain ISF A $\beta$ half-life and ISF A $\beta$ concentration in vivo}

The concentration of soluble $A \beta$ in the extracellular space (ISF) reflects a steady state determined by the rates of $\mathrm{A} \beta$ generation and elimination (Cirrito et al., 2003). Given that $\mathrm{A} \beta$ peptides are primarily generated within neurons then secreted into the ISF (Hartmann et al., 1997; Kamenetz et al., 2003), and AAVtransduced TFEB was expressed selectively in astrocytes by design, we postulated that enhanced astrocytic TFEB expression will stimulate uptake and degradation of $\mathrm{A} \beta$, in vivo, similar to that observed in vitro (Fig. 2). Accordingly, we transduced 2-month-old APP/PS1 mice with AAV8-GFAP-FLAG-TFEB and control AAV8-GFAP-eGFP viral particles to determine whether astrocytic TFEB expression impacts ISF A $\beta$. These studies were performed before the deposition of plaques (Yan et al., 2009) to determine the role of astrocytic TFEB in normal $\mathrm{A} \beta$ metabolism without the complicating factor of deposited $\mathrm{A} \beta$. We performed in vivo microdialysis to ascertain $\mathrm{A} \beta$ levels in the ISF 1 month after viral injection (Fig. 6A). TFEB-expressing mice had significantly lower steady-state concentration of ISF A $\beta$ (by $39 \%$ ) compared with control mice (Fig. $6 A, C$ ). After steady-state measures of ISF A $\beta$ were obtained, mice were administered the potent $\gamma$-secretase inhibitor, Compound E (Cirrito et al., 2011), and ISF 
A

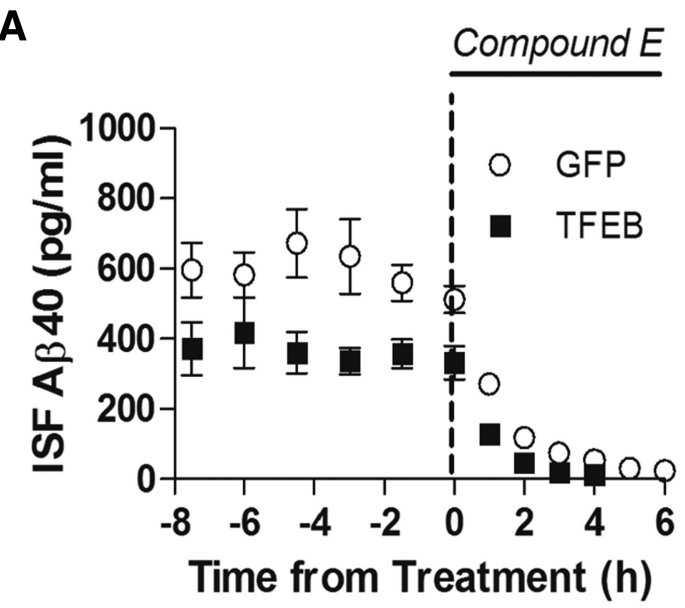

C

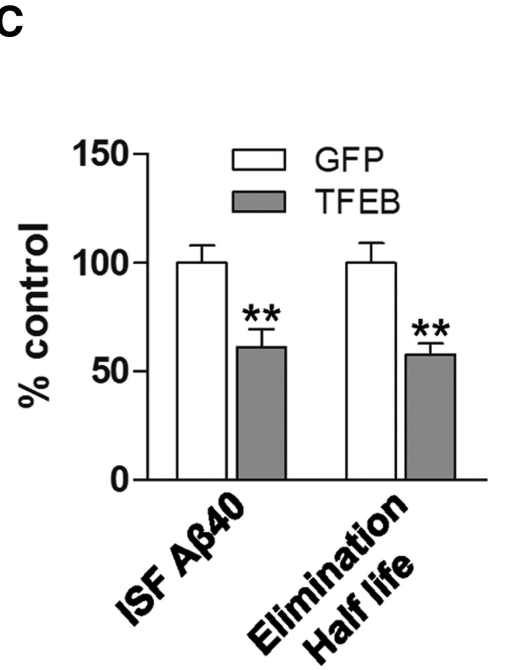

B

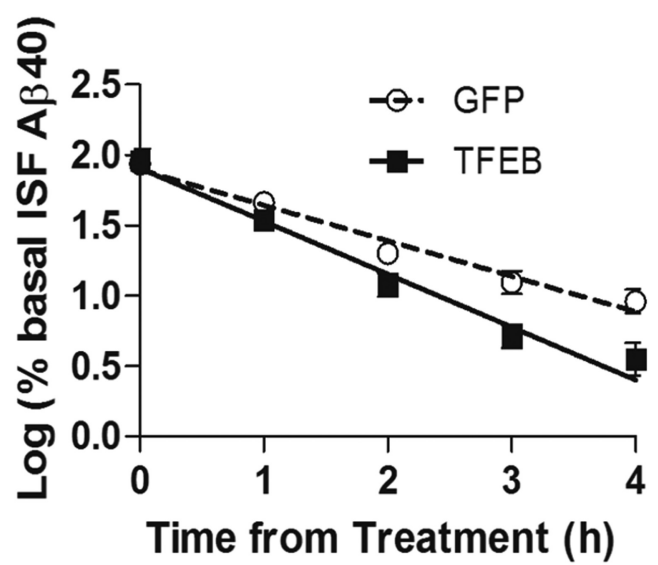

E
D

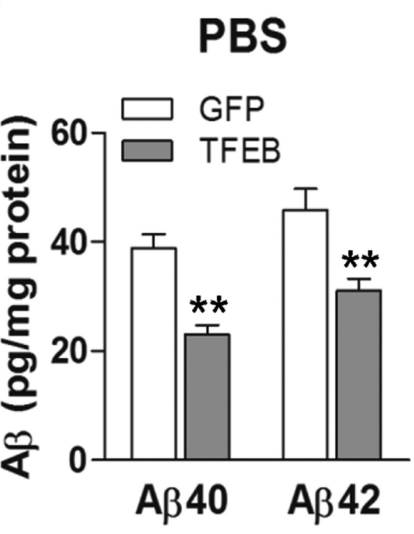

E

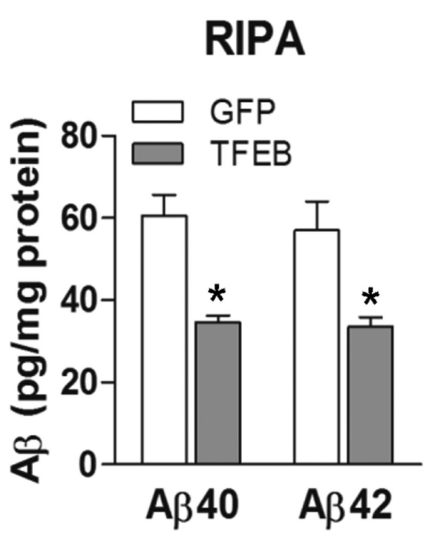

Figure 6. AAV8-mediated astrocytic gene transfer of TFEB reduces brain ISF A $\beta$ levels and reduces in vivo $A \beta$ half-life. $A$, Assessment of $A \beta$ levels by in vivo microdialysis in 3-month-old $A P P / P S 1$ mice transduced with AAV8-GFAP-FLAG-TFEB (TFEB) and AAV8-GFAP-eGFP (GFP) with serial hourly measurements. $N=5$ mice/group. At $t=0$, mice were continually administered Compound E directly to the hippocampus ( $200 \mathrm{~nm}$, reverse microdialysis) followed by hourly sampling for A $\beta$. Mean absolute in vivo "exchangeable" $A \beta$ (eA $\beta$ - 40 ) concentration was averaged over a $9 \mathrm{~h}$ period before drug administration, and assessed to be $362.4 \pm 49.0 \mathrm{pg} / \mathrm{ml}$ in TFEB-transduced mice versus $592.5 \pm 46.9 \mathrm{pg} / \mathrm{ml}$ in controls. $B$, Semi-log plot of decline in percentage basal ISF A $\beta$ levels during administration of Compound $\mathrm{E}$, in animals in $A$. Half-life in control mice was $1.26 \pm 0.11 \mathrm{~h}$ and $0.76 \pm 0.06 \mathrm{~h}$ in TFEB-expressing mice. C, Quantification of averaged concentration and elimination half-life of ISF $A \beta$ as calculated in $\boldsymbol{A}$ and $\boldsymbol{B}_{;}^{*}{ }^{* *} p<0.01 . \boldsymbol{D}, \boldsymbol{E}, A \beta 40$ and $A \beta 42$ levels in dissected hippocampal tissues from AAV8-GFAP-FLAG-TFEB (TFEB) and AAV8-GFAP-eGFP (GFP) transduced APP/PS1 mice (5 months of age). Tissue was homogenized first in PBS (D) and then in RIPA (E) quantified with ELISA assay. HJ2 and HJ7.4 antibodies were used for capture A $\beta 40$ and $A \beta 42$, respectively, and $H J 5.1$ antibody was used for detection. $N=5$ mice/group; ${ }^{*} p<0.05,{ }^{* *} p<0.01$.

was sampled for an additional $6 \mathrm{~h}$ to determine the elimination rate (half-life) of pre-existing $\mathrm{A} \beta$ (Fig. $6 A$ ). As shown, the elimination of ISF $A \beta$ followed first-order kinetics in both control and TFEB-expressing mice (Fig. 6B). Astrocytic expression of TFEB significantly reduced the in vivo elimination half-life of ISF $A \beta$ by $40 \%$, compared with controls (Fig. $6 B, C$ ), mirroring the magnitude of half-life reduction in in vitro studies (Fig. $2 C$ ). To confirm that the reduction in ISF $A \beta$ levels with astrocytic TFEB expression resulted in increased $\mathrm{A} \beta$ elimination, and not merely increased cellular uptake, we assessed total $\mathrm{A} \beta$ abundance in hippocampal tissue and observed a significant reduction in total immunodetectable $\mathrm{A} \beta$ levels in TFEB-transduced hippocampi (by $\sim 40 \%$ vs control, at this time point; Fig. $6 D, E$ ). This directly demonstrates that exogenous TFEB expression in astrocytes enhances $\mathrm{A} \beta$ degradation, in vivo.

We did not observe any significant difference in transcript levels for $A \beta$-binding receptors (LRP1, LDLR), chaperones (ApoE, Apo J), or A $\beta$ metabolizing enzymes (MMP2, MMP9, IDE, or Neprilysin) in the AAV-TFEB transduced hippocampi compared with controls (data not shown), suggesting that astrocytic TFEB expression does not alter the extracellular degradation or transport of $A \beta$ peptides. These observations are consistent with enhanced cellular uptake and degradation of A $\beta$ by TFEBtransduced astrocytes, in vivo, as observed in vitro (Figs. 2, 3 ).

Astrocytic TFEB expression reduces total $\mathrm{A} \beta$ levels and amyloid plaque load in APP/PS1 mice

To evaluate the effect of astrocytic TFEB expression on A $\beta$ levels and amyloid accumulation in aging mice, hippocampal tissue from the 10-month-old mice was sequentially homogenized in PBS followed by guanidine to extract PBS-soluble and -insoluble fractions (Yan et al., 2009). Each fraction was quantified using ELISAs to measure both $\mathrm{A} \beta 40$ and $\mathrm{A} \beta 42$. Exogenous TFEB expression resulted in a decrease in both PBS-soluble and insoluble fractions of $\mathrm{A} \beta 40$ and $\mathrm{A} \beta 42$ (Fig. $7 A, B$ ), to a comparable extent as observed in the ISF (Fig. $6 A, C$ ) and in the hippocampi from TFEB-transduced predepositing APP/PS1 mice (Fig. 6D, E). Importantly, expression of GFAP promoter-driven GFP used as 
A

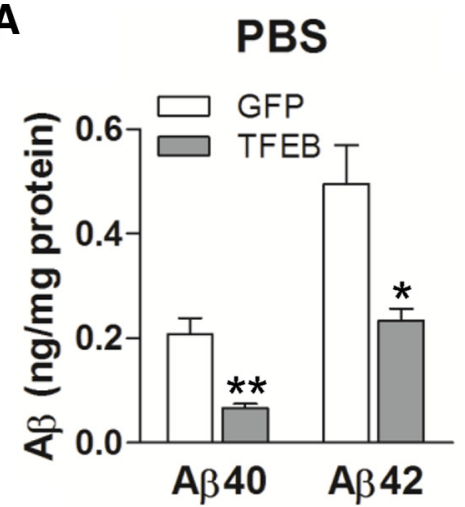

C

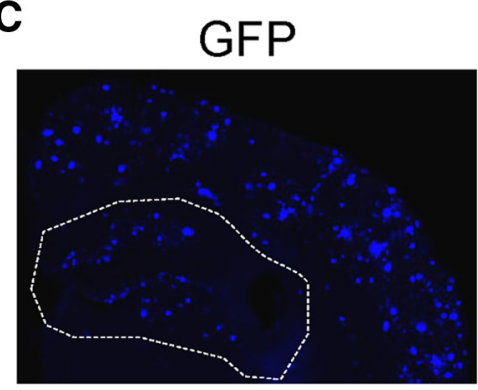

D

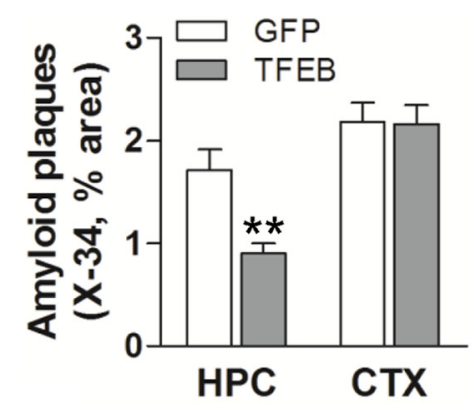

$\mathbf{F}$

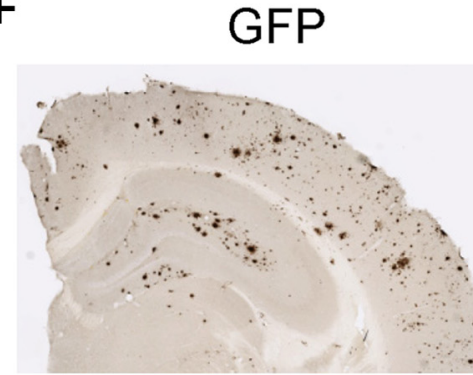

G

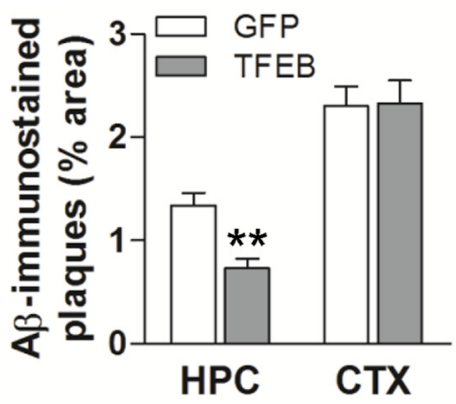

B

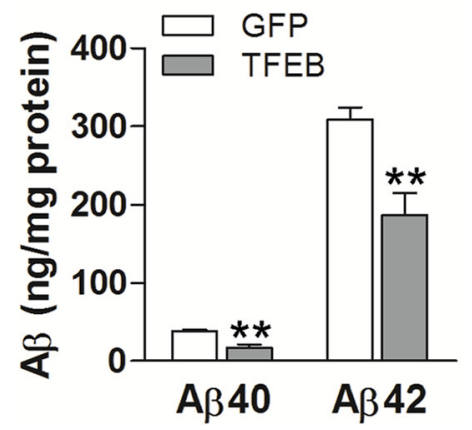

TFEB

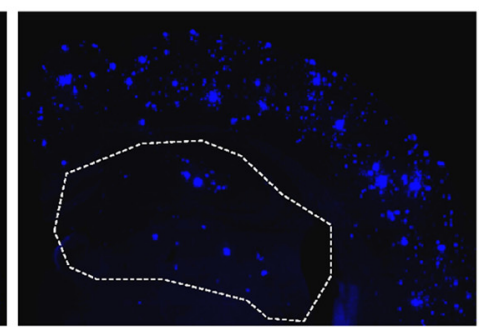

E
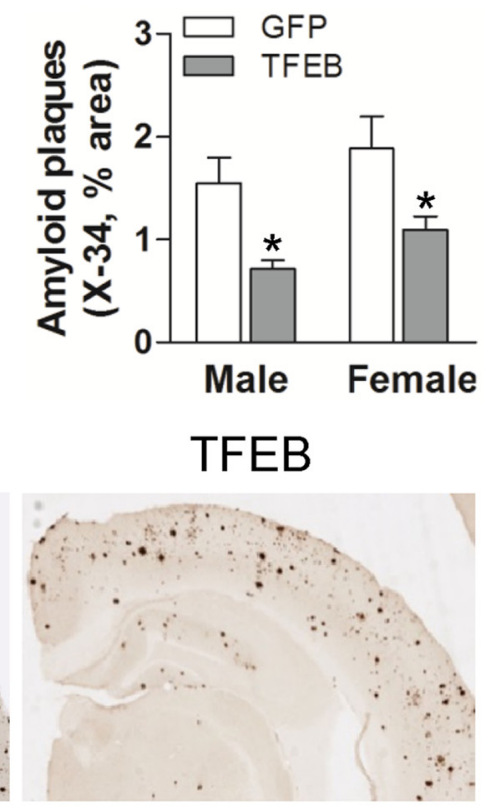

H

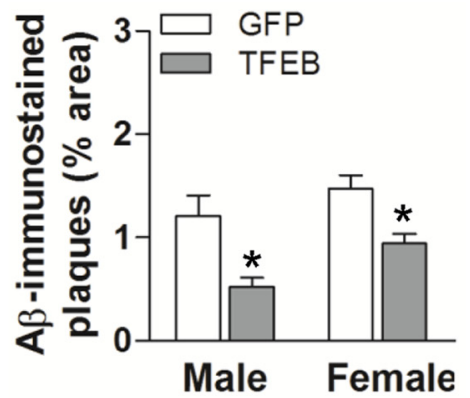

Figure 7. Astrocytic TFEB overexpression decreases amyloid plaque load in hippocampus of APP/PS1 mice. $A, B, A \beta 40$ and A $\beta 42$ levels in dissected hippocampal tissues from AAV8-GFAP-FLAG-TFEB (TFEB) and AAV8-GFAP-eGFP (GFP) transduced mice (10 months of age). Tissue was homogenized first in PBS (soluble levels, $\boldsymbol{A}$ ), then in 5 mm guanidine (insoluble levels, $\boldsymbol{B}$ ) quantified

control for these studies did not result in altered $\mathrm{A} \beta$ levels compared with uninjected age- and sex-matched mice (data not shown). These data indicate that exogenous TFEB enhanced both uptake and degradation of $\mathrm{A} \beta$ within astrocytes, in vivo.

To determine whether TFEB-mediated decline in ISF $A \beta$ influences amyloid plaque pathogenesis, we stained brain slices with X-34 to assess compact amyloid plaques and immunostained with anti- $\mathrm{A} \beta$ antibodies to assess $\mathrm{A} \beta$ plaque load. Quantitative analysis of X-34 staining (Fig. 7C) demonstrated that amyloid plaque load in TFEB-transduced hippocampus was significantly decreased (Fig. $7 D, E$ ) compared with control. This reduction was anatomically localized to the hippocampus (see area enclosed within dotted line), which was the site of experimental TFEB transduction, without an effect on cortical plaque load (Fig. 7D), consistent with a local effect of enhanced astrocyte $A \beta$ uptake and degradation. In addition, TFEB-stimulated reduction in plaque load was similar in magnitude in both sexes (Fig. 7E; $n=5 \mathrm{mice} / \mathrm{sex} /$ group), despite a higher plaque load observed in female mice, as previously described (Callahan et al., 2001). Similarly, TFEB-transduced hippocampi (but not the cortex) demonstrated significantly reduced $\mathrm{A} \beta$-immunostained plaque load (Fig. $7 F-H$ ) compared with control. The reduction in amyloid plaque load with TFEB expression (by $\sim 45 \%$ ) is consistent with the magnitude of decline in ISF $A \beta$ levels (by 40\%), mirroring previous observations, suggesting a robust effect of increased $\mathrm{A} \beta$ removal from the extracellular space on reducing amyloid plaque load (Yan et al., 2009). Collectively, these results indicate that astrocytic TFEB expression attenuates amyloid plaque accumulation, likely via enhancing $\mathrm{A} \beta$ uptake from the ISF and facilitating clearance via lysosomal degradation, in the brain.

$\leftarrow$

with ELISA assay. HJ2 and HJ7.4 antibodies were used for capture $A \beta 40$ and $A \beta 42$, respectively, and $H J 5.1$ antibody was used for detection. $N=8$ mice/group; ${ }^{* *} p<0.01$. C, Representative $X$-34-stained images from APP/PS1 mice treated as in $\boldsymbol{A}$. The area of the hippocampus is outlined with a dotted line. $\boldsymbol{D}, \boldsymbol{E}$, Quantification of $X$-34-stained plaque burden in the hippocampus in mice treated as in $\boldsymbol{A}(\boldsymbol{D})$ and plaque burden stratified by sex $(\boldsymbol{E}) . N=10$ ( 5 male and 5 female) mice/ group. $\boldsymbol{F}$, Representative $A \beta$-immunostained images from mice treated as in $\boldsymbol{A}$. $\boldsymbol{G}, \boldsymbol{H}$, Quantification of $A \beta$-stained plaque burden in the hippocampus in mice treated as in $\boldsymbol{A}(\boldsymbol{G})$ and plaque burden stratified by sex $(\boldsymbol{H}) . N=10(5$ male and 5 female) mice/group; ${ }^{*} p<0.05,{ }^{* *} p<0.01$. 


\section{Discussion}

We have demonstrated that targeted gene delivery of TFEB to astrocytes is effective in countering amyloid plaque pathogenesis. Specifically, astrocytic TFEB expression in the hippocampus (6to 9-fold above basal level) resulted in TFEB activation (localization to the nucleus) and induction of the lysosomal machinery, including enhanced Cathepsin B and D activity (Figs. 1, 4, 5). TFEB also stimulated $\mathrm{A} \beta$ uptake and degradation via lysosomes (Figs. 2, 3), resulting in significantly lower $\mathrm{A} \beta$ levels (Figs. 6, 7) and shortened $\mathrm{A} \beta$ half-life, both intracellularly as observed in vitro (Fig. 2) and extracellularly in the ISF (Fig. 6). This resulted in a substantial attenuation in amyloid plaque load (Fig. 7) in the hippocampus of APP/PS1 mice. These observations point to a direct effect of TFEB on stimulating $\mathrm{A} \beta$ degradation by astrocytes to attenuate amyloid plaque pathogenesis.

Astrocytes play a critical role in maintaining neuronal homeostasis by providing energy, eliminating waste, regulating transport across the blood-brain barrier, clearing neurotransmitters at the synapse, regulating cellular ionic fluxes, and mediating repair in response to injury (Eroglu and Barres, 2010). Moreover, astrocytes provide complete coverage of brain parenchyma by virtue of their territorial relationships, forming a mosaic with adjacent astrocytes (Bushong et al., 2002). Thus, astrocytes are well positioned both metabolically and anatomically to play an important homeostatic role under basal conditions and during disease pathogenesis. A prominent role for astrocytes in $\mathrm{AD}$ pathogenesis is evidenced by astrocyte activation early in the disease process (Schipper et al., 2006; Owen et al., 2009; Carter et al., 2012) together with their ability to take up and degrade $A \beta$ (Wyss-Coray et al., 2003; Koistinaho et al., 2004; Nielsen et al., 2009). These observations suggest that while astrocytes may participate in physiologic clearance of $\mathrm{A} \beta$ peptides to maintain their steady-state levels in the extracellular fluids in normal individuals (Bateman et al., 2006), their role in the removal of extracellular $\mathrm{A} \beta$ and amyloid material may be insufficient in the setting of $\mathrm{AD}$ (Wyss-Coray et al., 2003; Nielsen et al., 2009). Our results indicate that the ability of astrocytes to eliminate amyloid material may be enhanced or restored by stimulating TFEB-mediated trafficking and degradative pathways, as a therapeutic and/or preventive strategy in individuals predisposed to developing AD.

Astrocytes take up A $\beta$ bound to membrane receptors such as LDLR (Basak et al., 2012) or LRP1 (Verghese et al., 2013) via endocytosis. Multiple studies have demonstrated the efficacy of enhancing cellular uptake and degradation by overexpressing these receptors (Kim et al., 2009; Basak et al., 2012; Castellano et al., 2012). Glial cells may also take up $\mathrm{A} \beta$ bound to heparan sulfate proteoglycans by macropinocytosis (Mandrekar et al., 2009), involving invagination of the cell membrane to engulf extracellular material. In addition, activated astrocytes with hypertrophied processes exist in close contact with amyloid plaques, and have been postulated to phagocytose amyloid material (Funato et al., 1998; Wyss-Coray et al., 2003). Our data indicate that TFEB stimulates uptake of $\mathrm{A} \beta$ via heparan sulfate proteoglycans and macropinocytosis without affecting the $\mathrm{A} \beta$ binding receptors and endocytosis. The underlying molecular mechanisms for this observation warrant further exploration.

We and others have observed that $\mathrm{A} \beta$ is rapidly trafficked to the lysosomes after uptake (Kanekiyo et al., 2011; Basak et al., 2012) and exogenous TFEB accelerates this process. Degradation of $\mathrm{A} \beta$ requires intact lysosome function. Indeed, normal lysosome function in astrocytes is essential to prevent neurodegeneration, as targeted astrocytic ablation of sulfatase-modifying factor 1 (loss of function causing multiple sulfatase deficiencies), provokes degeneration of cortical neurons (Di Malta et al., 2012). Emerging evidence has fostered suspicion that aging-induced impairment in lysosome function facilitates pathogenesis in $\mathrm{AD}$ (Nixon and Cataldo, 2006; Wolfe et al., 2013). While it remains to be determined whether a specific impairment in astrocytic lysosome function causes or contributes to amyloid plaque deposition, our data indicate that upregulation of lysosomal numbers and enhanced lysosome function with TFEB-induced lysosome biogenesis (Settembre et al., 2011) is highly efficacious in facilitating $\mathrm{A} \beta$ and amyloid plaque elimination by astrocytes.

We have also found that exogenous TFEB expression results in increased abundance and activity of Cathepsin B and D, both in vitro and in vivo, which is likely involved in $\mathrm{A} \beta$ degradation. Evidence suggests that Cathepsin activity is essential for maintaining normal levels of $\mathrm{A} \beta$ in the extracellular space, as germline ablation of Cathepsin B increases $A \beta$ levels and worsens plaque deposition (Mueller-Steiner et al., 2006). Lentiviral transduction of Cathepsin B (Mueller-Steiner et al., 2006) or germline ablation of endogenous protease inhibitors such as cystatin C (Sun et al., 2008) and B (Yang et al., 2011) increases Cathepsin activity, reduces $\mathrm{A} \beta$ levels, and attenuates plaque deposition. Polymorphisms in the gene coding for Cathepsin D have been implicated in conferring increased risk for developing $\mathrm{AD}$ (Schuur et al., 2011), and Cathepsin D activity, reduced in AD mouse models (Avrahami et al., 2013), may be pharmacologically stimulated with inhibition of glycogen synthase kinase-3 $\beta$ (GSK3 $\beta$ ) to attenuate amyloid plaque pathogenesis. Aside from the specific induction of Cathepsin B and D, it is likely that other Cathepsins are induced (Palmieri et al., 2011) and mediate a general increase in lysosomal degradation.

Among other plausible subcellular mechanisms that may underlie TFEB-induced reduction in A $\beta$ levels, enhanced lysosomal acidification by transcription of the lysosomal proton pump machinery (Settembre et al., 2011; Roczniak-Ferguson et al., 2012) may be highly relevant. Indeed, TFEB expression may rectify the impaired acidification of lysosomes with aging (Wolfe et al., 2013), or with loss of presenilin, as observed in familial AD (Lee et al., 2010). TFEB also stimulates lysosomal calcium release (Medina et al., 2011) and promotes autophagosome-lysosome fusion (Settembre et al., 2011), which may be other mechanisms whereby TFEB may correct the lysosomal calcium storage and release defects observed with presenilin deficiency (Coen et al., 2012). The synergistic effect of these multiple TFEB-stimulated mechanisms may be to promote complete proteolysis of $A \beta$ and prevent aggregation into fibrils in an acidic environment ( $\mathrm{Hu}$ et al., 2009), in the setting of underlying impairment in lysosome function.

Astrocytes are "activated" (displaying hypertrophied processes and increased GFAP expression) surrounding amyloid plaques in humans with AD (Schipper et al., 2006; Owen et al., 2009; Carter et al., 2012) and in APP transgenic mouse models (Nagele et al., 2003; Wyss-Coray et al., 2003; Nielsen et al., 2009). Activated astrocytes are observed in virtually all neurodegenerative diseases. In some, it has been suggested that astrocyte activation may be protective, as impairment in astrocyte activation with targeted ablation of intermediate filament proteins, GFAP and vimentin, worsens the pathology in neuronal ceroid lipofuscinosis, a lysosomal storage disease (Macauley et al., 2011). Importantly, we have observed that activated astrocytes play a critical role in attenuating plaque pathogenesis (Kraft et al., 2013). TFEB may stimulate astrocyte activation and phagocytosis of amyloid material via its upregulation of the phagocytotic ma- 
chinery (Palmieri et al., 2011), an activity that warrants further investigation.

Reduced TFEB activation may underlie aging-related impairment in lysosomal function in AD (Nixon and Cataldo, 2006; Wolfe et al., 2013), a premise that needs further exploration. Indeed, insufficient TFEB activity has been implicated in causing lysosomal dysfunction in models of Parkinson's disease and AAV-mediated transduction of TFEB accelerated clearance of $\alpha$-synuclein and protection against cytotoxicity (Decressac et al., 2013). Activation of mTOR, which provokes phosphorylation and cytoplasmic retention of TFEB in diverse cell types (Zoncu et al., 2011; Settembre et al., 2012; Martina and Puertollano, 2013), is observed in AD mouse models (Lafay-Chebassier et al., 2005). Various studies have demonstrated attenuation of plaque pathology with pharmacological inhibition of $\mathrm{mTOR}$ and GSK3 $\beta$ (Cai et al., 2012; Avrahami et al., 2013) or administration of lysosomal modulator Z-Phe-Ala-diazomethylketone (Butler et al., 2011). Activation of TFEB with GSK3 $\beta$ inhibition in neural tissue indicates the need to examine the therapeutic efficacy of TFEB targeting to various cell types in countering $\mathrm{AD}$ pathogenesis. Although small molecules that enhance TFEB expression have not been extensively explored, a recent study suggests that identification of such agents may be feasible (Song et al., 2014). Further studies are also needed to examine possible adverse effects of targeting TFEB activity, but current studies do not reveal obvious adverse effects (Tsunemi et al., 2012; Decressac et al., 2013).

A major strength of our viral gene transfer approach is the rapid assessment of cellular and molecular mechanisms involved in amyloid plaque pathogenesis, exploiting regional differences (targeting hippocampus) in cell-autonomous effects to establish specificity of targeting TFEB in astrocytes. However, focal targeting of TFEB expression to the hippocampus precludes an evaluation of its effects on cognitive parameters or neuronal pathology, which is not observed in the APP/PS1 model. Notwithstanding these limitations, our data demonstrate that TFEB activation enhances $A \beta$ uptake and degradation in astrocytes, thereby lowering ISF $A \beta$ concentrations and resulting in decreased plaque load. This study lays the foundation for exploring therapeutic strategies targeting TFEB activation, either pharmacologically or via gene therapy, both globally and in specific cell types, to counter $\mathrm{AD}$ pathogenesis.

\section{References}

Avrahami L, Farfara D, Shaham-Kol M, Vassar R, Frenkel D, EldarFinkelman H (2013) Inhibition of glycogen synthase kinase-3 ameliorates beta-amyloid pathology and restores lysosomal acidification and mammalian target of rapamycin activity in the Alzheimer disease mouse model: in vivo and in vitro studies. J Biol Chem 288:1295-1306. CrossRef Medline

Baldo G, Wu S, Howe RA, Ramamoothy M, Knutsen RH, Fang J, Mecham RP, Liu Y, Wu X, Atkinson JP, Ponder KP (2011) Pathogenesis of aortic dilatation in mucopolysaccharidosis VII mice may involve complement activation. Mol Genet Metab 104:608-619. CrossRef Medline

Barres BA (2008) The mystery and magic of glia: a perspective on their roles in health and disease. Neuron 60:430-440. CrossRef Medline

Basak JM, Verghese PB, Yoon H, Kim J, Holtzman DM (2012) Low-density lipoprotein receptor represents an apolipoprotein E-independent pathway of Abeta uptake and degradation by astrocytes. J Biol Chem 287: 13959-13971. CrossRef Medline

Bateman RJ, Munsell LY, Morris JC, Swarm R, Yarasheski KE, Holtzman DM (2006) Human amyloid-beta synthesis and clearance rates as measured in CSF in vivo. Nat Med 12:856-861. CrossRef Medline

Brenner M, Kisseberth WC, Su Y, Besnard F, Messing A (1994) GFAP promoter directs astrocyte-specific expression in transgenic mice. J Neurosci 14:1030-1037. Medline

Bushong EA, Martone ME, Jones YZ, Ellisman MH (2002) Protoplasmic astrocytes in CA1 stratum radiatum occupy separate anatomical domains. J Neurosci 22:183-192. Medline

Butler D, Hwang J, Estick C, Nishiyama A, Kumar SS, Baveghems C, YoungOxendine HB, Wisniewski ML, Charalambides A, Bahr BA (2011) Protective effects of positive lysosomal modulation in Alzheimer's disease transgenic mouse models. PLoS One 6:e20501. CrossRef Medline

Cai Z, Zhao B, Li K, Zhang L, Li C, Quazi SH, Tan Y (2012) Mammalian target of rapamycin: a valid therapeutic target through the autophagy pathway for Alzheimer's disease? J Neurosci Res 90:1105-1118. CrossRef Medline

Callahan MJ, Lipinski WJ, Bian F, Durham RA, Pack A, Walker LC (2001) Augmented senile plaque load in aged female beta-amyloid precursor protein-transgenic mice. Am J Pathol 158:1173-1177. CrossRef Medline

Carter SF, Schöll M, Almkvist O, Wall A, Engler H, Långström B, Nordberg A (2012) Evidence for astrocytosis in prodromal Alzheimer disease provided by 11C-deuterium-L-deprenyl: a multitracer PET paradigm combining 11C-Pittsburgh compound B and 18F-FDG. J Nucl Med 53:37-46. CrossRef Medline

Castellano JM, Deane R, Gottesdiener AJ, Verghese PB, Stewart FR, West T, Paoletti AC, Kasper TR, DeMattos RB, Zlokovic BV, Holtzman DM (2012) Low-density lipoprotein receptor overexpression enhances the rate of brain-to-blood Abeta clearance in a mouse model of betaamyloidosis. Proc Natl Acad Sci U S A 109:15502-15507. CrossRef Medline

Cirrito JR, May PC, O’Dell MA, Taylor JW, Parsadanian M, Cramer JW, Audia JE, Nissen JS, Bales KR, Paul SM, DeMattos RB, Holtzman DM (2003) In vivo assessment of brain interstitial fluid with microdialysis reveals plaque-associated changes in amyloid-beta metabolism and halflife. J Neurosci 23:8844-8853. Medline

Cirrito JR, Disabato BM, Restivo JL, Verges DK, Goebel WD, Sathyan A Hayreh D, D'Angelo G, Benzinger T, Yoon H, Kim J, Morris JC, Mintun MA, Sheline YI (2011) Serotonin signaling is associated with lower amyloid-beta levels and plaques in transgenic mice and humans. Proc Natl Acad Sci U S A 108:14968-14973. CrossRef Medline

Coen K, Flannagan RS, Baron S, Carraro-Lacroix LR, Wang D, Vermeire W, Michiels C, Munck S, Baert V, Sugita S, Wuytack F, Hiesinger PR, Grinstein S, Annaert W (2012) Lysosomal calcium homeostasis defects, not proton pump defects, cause endo-lysosomal dysfunction in PSENdeficient cells. J Cell Biol 198:23-35. CrossRef Medline

Cuervo AM, Dice JF (2000) When lysosomes get old. Exp Gerontol 35:119131. CrossRef Medline

Decressac M, Mattsson B, Weikop P, Lundblad M, Jakobsson J, Björklund A (2013) TFEB-mediated autophagy rescues midbrain dopamine neurons from alpha-synuclein toxicity. Proc Natl Acad Sci U S A 110:E1817E1826. CrossRef Medline

Di Malta C, Fryer JD, Settembre C, Ballabio A (2012) Astrocyte dysfunction triggers neurodegeneration in a lysosomal storage disorder. Proc Natl Acad Sci U S A 109:E2334-E2342. CrossRef Medline

Eroglu C, Barres BA (2010) Regulation of synaptic connectivity by glia. Nature 468:223-231. CrossRef Medline

Fan TC, Chang HT, Chen IW, Wang HY, Chang MD (2007) A heparan sulfate-facilitated and raft-dependent macropinocytosis of eosinophil cationic protein. Traffic 8:1778-1795. CrossRef Medline

Funato H, Yoshimura M, Yamazaki T, Saido TC, Ito Y, Yokofujita J, Okeda R, Ihara Y (1998) Astrocytes containing amyloid beta-protein (Abeta)positive granules are associated with Abeta40-positive diffuse plaques in the aged human brain. Am J Pathol 152:983-992. Medline

Gong Y, Chang L, Viola KL, Lacor PN, Lambert MP, Finch CE, Krafft GA, Klein WL (2003) Alzheimer's disease-affected brain: presence of oligomeric A beta ligands (ADDLs) suggests a molecular basis for reversible memory loss. Proc Natl Acad Sci U S A 100:10417-10422. CrossRef Medline

Hardy J, Selkoe DJ (2002) The amyloid hypothesis of Alzheimer's disease: progress and problems on the road to therapeutics. Science 297:353-356. CrossRef Medline

Hartmann T, Bieger SC, Brühl B, Tienari PJ, Ida N, Allsop D, Roberts GW, Masters CL, Dotti CG, Unsicker K, Beyreuther K (1997) Distinct sites of intracellular production for Alzheimer's disease A beta40/42 amyloid peptides. Nat Med 3:1016-1020. CrossRef Medline

Holmes BB, DeVos SL, Kfoury N, Li M, Jacks R, Yanamandra K, Ouidja MO, Brodsky FM, Marasa J, Bagchi DP, Kotzbauer PT, Miller TM, PapyGarcia D, Diamond MI (2013) Heparan sulfate proteoglycans mediate 
internalization and propagation of specific proteopathic seeds. Proc Natl Acad Sci U S A 110:E3138-E3147. CrossRef Medline

Hu X, Crick SL, Bu G, Frieden C, Pappu RV, Lee JM (2009) Amyloid seeds formed by cellular uptake, concentration, and aggregation of the amyloid-beta peptide. Proc Natl Acad Sci U S A 106:20324-20329. CrossRef Medline

Jankowsky JL, Fadale DJ, Anderson J, Xu GM, Gonzales V, Jenkins NA, Copeland NG, Lee MK, Younkin LH, Wagner SL, Younkin SG, Borchelt DR (2004) Mutant presenilins specifically elevate the levels of the 42 residue beta-amyloid peptide in vivo: evidence for augmentation of a 42 -specific gamma secretase. Hum Mol Genet 13:159-170. Medline

Kamenetz F, Tomita T, Hsieh H, Seabrook G, Borchelt D, Iwatsubo T, Sisodia S, Malinow R (2003) APP processing and synaptic function. Neuron 37:925-937. CrossRef Medline

Kanekiyo T, Zhang J, Liu Q, Liu CC, Zhang L, Bu G (2011) Heparan sulphate proteoglycan and the low-density lipoprotein receptor-related protein 1 constitute major pathways for neuronal amyloid-beta uptake. J Neurosci 31:1644-1651. CrossRef Medline

Kato Y, Maruyama W, Naoi M, Hashizume Y, Osawa T (1998) Immunohistochemical detection of dityrosine in lipofuscin pigments in the aged human brain. FEBS Lett 439:231-234. CrossRef Medline

Kim J, Castellano JM, Jiang H, Basak JM, Parsadanian M, Pham V, Mason SM, Paul SM, Holtzman DM (2009) Overexpression of low-density lipoprotein receptor in the brain markedly inhibits amyloid deposition and increases extracellular A beta clearance. Neuron 64:632-644. CrossRef Medline

Koistinaho M, Lin S, Wu X, Esterman M, Koger D, Hanson J, Higgs R, Liu F, Malkani S, Bales KR, Paul SM (2004) Apolipoprotein E promotes astrocyte colocalization and degradation of deposited amyloid-beta peptides. Nat Med 10:719-726. CrossRef Medline

Kraft AW, Hu X, Yoon H, Yan P, Xiao Q, Wang Y, Gil SC, Brown J, Wilhelmsson U, Restivo JL, Cirrito JR, Holtzman DM, Kim J, Pekny M, Lee JM (2013) Attenuating astrocyte activation accelerates plaque pathogenesis in APP/PS1 mice. FASEB J 27:187-198. CrossRef Medline

Lafay-Chebassier C, Paccalin M, Page G, Barc-Pain S, Perault-Pochat MC, Gil R, Pradier L, Hugon J (2005) mTOR/p70S6k signalling alteration by Abeta exposure as well as in APP-PS1 transgenic models and in patients with Alzheimer's disease. J Neurochem 94:215-225. CrossRef Medline

Lee JH, Yu WH, Kumar A, Lee S, Mohan PS, Peterhoff CM, Wolfe DM, Martinez-Vicente M, Massey AC, Sovak G, Uchiyama Y, Westaway D, Cuervo AM, Nixon RA (2010) Lysosomal proteolysis and autophagy require presenilin 1 and are disrupted by Alzheimer-related PS1 mutations. Cell 141:1146-1158. CrossRef Medline

Lomakin A, Teplow DB, Kirschner DA, Benedek GB (1997) Kinetic theory of fibrillogenesis of amyloid beta-protein. Proc Natl Acad Sci U S A 94: 7942-7947. CrossRef Medline

Ma X, Liu H, Foyil SR, Godar RJ, Weinheimer CJ, Hill JA, Diwan A (2012) Impaired autophagosome clearance contributes to cardiomyocyte death in ischemia/reperfusion injury. Circulation 125:3170-3181. CrossRef Medline

Macauley SL, Pekny M, Sands MS (2011) The role of attenuated astrocyte activation in infantile neuronal ceroid lipofuscinosis. J Neurosci 31: 15575-15585. CrossRef Medline

Mandrekar S, Jiang Q, Lee CY, Koenigsknecht-Talboo J, Holtzman DM, Landreth GE (2009) Microglia mediate the clearance of soluble Abeta through fluid phase macropinocytosis. J Neurosci 29:4252-4262. CrossRef Medline

Martina JA, Puertollano R (2013) Rag GTPases mediate amino aciddependent recruitment of TFEB and MITF to lysosomes. J Cell Biol 200: 475-491. CrossRef Medline

Mawuenyega KG, Sigurdson W, Ovod V, Munsell L, Kasten T, Morris JC, Yarasheski KE, Bateman RJ (2010) Decreased clearance of CNS betaamyloid in Alzheimer's disease. Science 330:1774. CrossRef Medline

Medina DL, Fraldi A, Bouche V, Annunziata F, Mansueto G, Spampanato C, Puri C, Pignata A, Martina JA, Sardiello M, Palmieri M, Polishchuk R, Puertollano R, Ballabio A (2011) Transcriptional activation of lysosomal exocytosis promotes cellular clearance. Dev Cell 21:421-430. CrossRef Medline

Menacherry S, Hubert W, Justice JB Jr (1992) In vivo calibration of microdialysis probes for exogenous compounds. Anal Chem 64:577-583. CrossRef Medline

Mousavi SA, Kjeken R, Berg TO, Seglen PO, Berg T, Brech A (2001) Effects of inhibitors of the vacuolar proton pump on hepatic heterophagy and autophagy. Biochim Biophys Acta 1510:243-257. CrossRef Medline

Mueller-Steiner S, Zhou Y, Arai H, Roberson ED, Sun B, Chen J, Wang X, Yu G, Esposito L, Mucke L, Gan L (2006) Antiamyloidogenic and neuroprotective functions of cathepsin B: implications for Alzheimer's disease. Neuron 51:703-714. CrossRef Medline

Nagele RG, D'Andrea MR, Lee H, Venkataraman V, Wang HY (2003) Astrocytes accumulate $\mathrm{A}$ beta 42 and give rise to astrocytic amyloid plaques in Alzheimer disease brains. Brain Res 971:197-209. CrossRef Medline

Nielsen HM, Veerhuis R, Holmqvist B, Janciauskiene S (2009) Binding and uptake of A beta 1-42 by primary human astrocytes in vitro. Glia 57:978 988. CrossRef Medline

Nixon RA, Cataldo AM (2006) Lysosomal system pathways: genes to neurodegeneration in Alzheimer's disease. J Alzheimers Dis 9:277-289. Medline

Owen JB, Di Domenico F, Sultana R, Perluigi M, Cini C, Pierce WM, Butterfield DA (2009) Proteomics-determined differences in the concanavalin-Afractionated proteome of hippocampus and inferior parietal lobule in subjects with Alzheimer's disease and mild cognitive impairment: implications for progression of AD. J Proteome Res 8:471-482. CrossRef Medline

Palmieri M, Impey S, Kang H, di Ronza A, Pelz C, Sardiello M, Ballabio A (2011) Characterization of the CLEAR network reveals an integrated control of cellular clearance pathways. Hum Mol Genet 20:3852-3866. CrossRef Medline

Peña-Llopis S, Vega-Rubin-de-Celis S, Schwartz JC, Wolff NC, Tran TA, Zou L, Xie XJ, Corey DR, Brugarolas J (2011) Regulation of TFEB and V-ATPases by mTORC1. EMBO J 30:3242-3258. CrossRef Medline

Roczniak-Ferguson A, Petit CS, Froehlich F, Qian S, Ky J, Angarola B, Walther TC, Ferguson SM (2012) The transcription factor TFEB links mTORC1 signaling to transcriptional control of lysosome homeostasis. Sci Signal 5:ra42. CrossRef Medline

Roh JH, Huang Y, Bero AW, Kasten T, Stewart FR, Bateman RJ, Holtzman DM (2012) Disruption of the sleep-wake cycle and diurnal fluctuation of beta-amyloid in mice with Alzheimer's disease pathology. Sci Transl Med 4:150ra122. CrossRef Medline

Sardiello M, Palmieri M, di Ronza A, Medina DL, Valenza M, Gennarino VA, Di Malta C, Donaudy F, Embrione V, Polishchuk RS, Banfi S, Parenti G, Cattaneo E, Ballabio A (2009) A gene network regulating lysosomal biogenesis and function. Science 325:473-477. CrossRef Medline

Schipper HM, Bennett DA, Liberman A, Bienias JL, Schneider JA, Kelly J, Arvanitakis Z (2006) Glial heme oxygenase-1 expression in Alzheimer disease and mild cognitive impairment. Neurobiol Aging 27:252-261. CrossRef Medline

Schuur M, Ikram MA, van Swieten JC, Isaacs A, Vergeer-Drop JM, Hofman A, Oostra BA, Breteler MM, van Duijn CM (2011) Cathepsin D gene and the risk of Alzheimer's disease: a population-based study and metaanalysis. Neurobiol Aging 32:1607-1614. CrossRef Medline

Settembre C, Di Malta C, Polito VA, Garcia Arencibia M, Vetrini F, Erdin S, Erdin SU, Huynh T, Medina D, Colella P, Sardiello M, Rubinsztein DC, Ballabio A (2011) TFEB links autophagy to lysosomal biogenesis. Science 332:1429-1433. CrossRef Medline

Settembre C, Zoncu R, Medina DL, Vetrini F, Erdin S, Huynh T, Ferron M, Karsenty G, Vellard MC, Facchinetti V, Sabatini DM, Ballabio A (2012) A lysosome-to-nucleus signalling mechanism senses and regulates the lysosome via mTOR and TFEB. EMBO J 31:1095-1108. CrossRef Medline

Settembre C, Fraldi A, Medina DL, Ballabio A (2013a) Signals from the lysosome: a control centre for cellular clearance and energy metabolism. Nat Rev Mol Cell Biol 14:283-296. CrossRef Medline

Settembre C, De Cegli R, Mansueto G, Saha PK, Vetrini F, Visvikis O, Huynh T, Carissimo A, Palmer D, Klisch TJ, Wollenberg AC, Di Bernardo D, Chan L, Irazoqui JE, Ballabio A (2013b) TFEB controls cellular lipid metabolism through a starvation-induced autoregulatory loop. Nat Cell Biol 15:647-658. CrossRef Medline

Song W, Wang F, Lotfi P, Sardiello M, Segatori L (2014) 2-Hydroxypropylbeta-cyclodextrin promotes transcription factor EB-mediated activation of autophagy: implications for therapy. J Biol Chem 289:10211-10222. CrossRef Medline

Sun B, Zhou Y, Halabisky B, Lo I, Cho SH, Mueller-Steiner S, Devidze N, Wang X, Grubb A, Gan L (2008) Cystatin C-cathepsin B axis regulates amyloid beta levels and associated neuronal deficits in an animal model of Alzheimer's disease. Neuron 60:247-257. CrossRef Medline 
Tsunemi T, Ashe TD, Morrison BE, Soriano KR, Au J, Roque RA, Lazarowski ER, Damian VA, Masliah E, La Spada AR (2012) PGC-1alpha rescues Huntington's disease proteotoxicity by preventing oxidative stress and promoting TFEB function. Sci Transl Med 4:142ra97. CrossRef Medline

Verges DK, Restivo JL, Goebel WD, Holtzman DM, Cirrito JR (2011) Opposing synaptic regulation of amyloid-beta metabolism by NMDA receptors in vivo. J Neurosci 31:11328-11337. CrossRef Medline

Verghese PB, Castellano JM, Garai K, Wang Y, Jiang H, Shah A, Bu G, Frieden C, Holtzman DM (2013) ApoE influences amyloid-beta (Abeta) clearance despite minimal apoE/Abeta association in physiological conditions. Proc Natl Acad Sci U S A 110:E1807-1816. CrossRef Medline

West MJ, Slomianka L, Gundersen HJ (1991) Unbiased stereological estimation of the total number of neurons in the subdivisions of the rat hippocampus using the optical fractionator. Anat Rec 231:482-497. CrossRef Medline

Wolfe DM, Lee JH, Kumar A, Lee S, Orenstein SJ, Nixon RA (2013) Autophagy failure in Alzheimer's disease and the role of defective lysosomal acidification. Eur J Neurosci 37:1949-1961. CrossRef Medline

Wyss-Coray T, Loike JD, Brionne TC, Lu E, Anankov R, Yan F, Silverstein SC, Husemann J (2003) Adult mouse astrocytes degrade amyloid-beta in vitro and in situ. Nat Med 9:453-457. CrossRef Medline

Xiao Q, Gil SC, Yan P, Wang Y, Han S, Gonzales E, Perez R, Cirrito JR, Lee JM (2012) Role of phosphatidylinositol clathrin assembly lymphoidmyeloid leukemia (PICALM) in intracellular amyloid precursor protein
(APP) processing and amyloid plaque pathogenesis. J Biol Chem 287: 21279-21289. CrossRef Medline

Yamamoto A, Tagawa Y, Yoshimori T, Moriyama Y, Masaki R, Tashiro Y (1998) Bafilomycin Al prevents maturation of autophagic vacuoles by inhibiting fusion between autophagosomes and lysosomes in rat hepatoma cell line, H-4-II-E cells. Cell Struct Funct 23:33-42. CrossRef Medline

Yan P, Bero AW, Cirrito JR, Xiao Q, Hu X, Wang Y, Gonzales E, Holtzman DM, Lee JM (2009) Characterizing the appearance and growth of amyloid plaques in APP/PS1 mice. J Neurosci 29:10706-10714. CrossRef Medline

Yang DS, Stavrides P, Mohan PS, Kaushik S, Kumar A, Ohno M, Schmidt SD, Wesson D, Bandyopadhyay U, Jiang Y, Pawlik M, Peterhoff CM, Yang AJ, Wilson DA, St George-Hyslop P, Westaway D, Mathews PM, Levy E, Cuervo AM, Nixon RA (2011) Reversal of autophagy dysfunction in the TgCRND8 mouse model of Alzheimer's disease ameliorates amyloid pathologies and memory deficits. Brain 134:258-277. CrossRef Medline

Zang Y, Yu LF, Pang T, Fang LP, Feng X, Wen TQ, Nan FJ, Feng LY, Li J (2008) AICAR induces astroglial differentiation of neural stem cells via activating the JAK/STAT3 pathway independently of AMP-activated protein kinase. J Biol Chem 283:6201-6208. CrossRef Medline

Zoncu R, Bar-Peled L, Efeyan A, Wang S, Sancak Y, Sabatini DM (2011) mTORC1 senses lysosomal amino acids through an inside-out mechanism that requires the vacuolar $\mathrm{H}(+)$-ATPase. Science 334:678-683. CrossRef Medline 